\title{
Are There Social Spillovers in Consumers' Security Assessments of Payment Instruments?
}

\author{
Charles M. Kahn, José M. Liñares-Zegarra, and Joanna Stavins *
}

\begin{abstract}
:
Even though security of payments has long been identified as an important aspect of the consumer payment experience, recent literature fails to appropriately assess the extent of social spillovers among payment users. We test for the existence and importance of such spillovers by analyzing whether social influence affects consumers' perceptions of the security of payment instruments. Based on a 2008-2014 annual panel data survey of consumers, we find strong evidence of social spillovers in payment markets: others' perceptions of security of payment instruments exert a positive influence on one's own payment security perceptions. The significant and robust results imply that a consumer's assessments of security converge to his peers' average assessment: a 10 percent change in the divergence between one's own security rating and peers' average rating will result in a 7 percent change in one's own rating in the next period. The results are robust to many specifications and do not change when we control for actual fraud or crime data.

Our results indicate that spillovers rather than reflection appear to be the cause, although separating the two causes is very difficult (Manski 1993). In particular, the spillovers are stronger for people who experience an exogenous shock to security perception, people who have more social interactions, and younger consumers, who are more likely to be influenced by social media. We also examine the effects of social spillovers on payment behavior (that is, on decisions regarding payment adoption and use). Our results indicate that social spillovers have a rather limited impact on payment behavior, as others' perceptions seem to affect one's own payment behavior mainly indirectly through the effect on one's own perceptions.
\end{abstract}

JEL Classifications: D12, G02, G20

\footnotetext{
* Charles M. Kahn is a professor emeritus of finance in the College of Business at the University of Illinois, José M. Liñares-Zegarra is a lecturer in finance in the Essex Business School at the University of Essex in the United Kingdom, and Joanna Stavins is a senior economist and policy advisor in the research department of the Federal Reserve Bank of Boston. Their e-mail addresses are c-kahn@illinois.edu, jmlina@essex.ac.uk, and joanna.stavins@bos.frb.org, respectively. We thank Mary Burke, Anneke Kosse, Scott Schuh, Helmut Stix, Robert Triest, John O.S. Wilson, and participants at the DeNederlandsche Bank Payments Conference and the Wolpertinger Conference for helpful comments and suggestions. Allison Cole provided excellent research assistance. The views expressed here do not necessarily reflect those of the Federal Reserve Bank of Boston or the Federal Reserve System.
} 


\section{Introduction}

Over the past decade, a number of developments in retail payments have emerged. While traditional payment methods, such as cash and checks, remain important, the increasing penetration of new technologies has provided consumers with access to new, moresophisticated payment solutions. The vast majority of U.S. consumers hold a diversified portfolio of payment instruments to conduct transactions. In 2013, on average, a U.S. consumer held 5.2 instrument types out of nine common instruments tracked by the Survey of Consumer Payment Choice (Schuh and Stavins 2015a).

A substantial and growing body of payment literature has developed on the determinants of adoption and use of payment methods (Koulayev et al. 2016, Schuh and Stavins 2010, 2013, Borzekowski and Kiser 2008). More recently, attention has focused on the role of fraud and security in driving payment choice (Kahn and Liñares-Zegarra 2015, Schuh and Stavins 2015b). ${ }^{1}$ This is consistent with the Federal Reserve's Financial Services Strategic Plan, which identifies security improvements as one of its top initiatives (Stavins 2013, Federal Reserve System 2015a,b). In almost every annual Survey of Consumer Payment Choice, consumers select security as the most important aspect of payments, above cost, convenience, and other attributes (Schuh and Stavins 2015a). Shortcomings in the safety of particular payments instruments, whether real or perceived, could compromise the smooth operation of entire retail payment systems and make payment users shift toward less-efficient means of payment. A deeper understanding of the determinants of safety perceptions is fundamental for helping policymakers and central bankers preserve consumers' confidence in payment instruments.

\footnotetext{
${ }^{1}$ Despite the implementation of increasingly sophisticated security standards by the payments industry, fraud and data breaches are still an important threat to both payment providers and consumers. Data breaches likely contributed to concerns about security and may affect the choice of payment providers or methods (Cheney et al. 2012). Skimming fraud, identity theft, and security failures have compromised growing numbers of payment records (Sullivan 2010). In addition, the increasing number of retail payment instruments available to U.S. consumers may be generating new and more-sophisticated forms of payment fraud.
} 
Recent literature offers insights on the importance of safety in payment choice, but fails to appropriately assess the importance of social spillovers among payment users. This is somewhat surprising, given the evidence that people's financial choices are often influenced by the choices made by those around them (Bursztyn et al. 2014). Our paper attempts to fill this gap by (i) studying whether consumers' perceived safety of payment instruments is influenced by their peers' perceptions of safety, and (ii) examining the effects of their peers' perceptions on their own adoption and use of payment instruments. The annual Survey of Consumer Payment Choice (SCPC) becomes an important tool in achieving these aims. The SCPC is a longitudinal panel of U.S. consumers conducted from 2008 to 2014. The SCPC is one of the few publicly available, nationally representative surveys with micro-data on payment choices and consumer payment behavior in the United States. The data provide a relatively good approximation of the norm in terms of payment behavior and therefore of the aggregate average behavior of payment users.

The existing literature has relied on individuals' perceptions to explain payment behavior, but has provided limited insights on how perceptions are formed. In the context of security, it might be expected that in addition to any direct effects of the consumer's own perceptions of security, there might be additional social spillovers of others' perceptions on one's own behavior: one's own perceptions of the risk associated with using credit cards, for example, might be affected by what other people think those risks are (that is, there might be informational cascades or consumers learning by observing others). The transmission of perceptions across individuals could occur either through direct interactions with peers or through spillovers of information transmitted via news channels and social media. For example, a consumer's own perception could converge to the average perception of others after the consumer learned about payments security from media reports - either traditional or social -in addition to learning directly from his peers. Such announcements and reports could be issued following any external shocks involving payments security. The shocks might not affect the consumer directly, but rather might affect him indirectly via such spillover effects. 
Convergence based on the consumer learning from media reports would not be considered a spillover, but rather would be considered reflection (Manski 1993) or a "correlated effect," where both the consumer and his peers are looking at the same reports, and their perceptions converge based on all learning from that same report. However, learning directly from peers is a social spillover. We perform some tests to try to determine whether our results are caused by reflection or by spillovers.

Our results provide strong evidence of the existence of social spillovers in consumers' security assessments: we observe a positive influence of peers' perceptions of security on consumers' own perceptions of security. In particular, the results suggest that the consumer's own perceptions of security tend to converge to the average perception, both nationally and in the U.S. state where the consumer lives. This result is both statistically significant and economically large. While the findings are consistent with social spillovers, they are also consistent with spillovers of information. The data do not allow us to distinguish among the different mechanisms through which the spillover effects occur.

The results are robust to a number of alternative specifications that suggest no substantial changes in our main results. First, since individuals within a state might share some characteristics, such as values, norms, work ethics, consumption and payment patterns (contextual effects) and be affected by common shocks (correlated effects), it could give a false appearance of a peer effect. To mitigate these concerns, we use a number of approaches: $(i)$ in all specifications we include time dummies to capture common shocks affecting all individuals simultaneously, (ii) in some of our models we also control for time-varying crime rates in the state of residence of consumer $i$ (the variable acts as a region-year dummy to capture local common shocks), (iii) our models include a payment instrument fixed effect to control for supply-side and external shocks, which could affect perceptions for a specific payment instrument across all individuals living in a state. ${ }^{2}$ Second, we address the possibility that an

\footnotetext{
${ }^{2}$ Other unreported specifications - available upon request - included individual fixed effects, which capture both (unobserved) characteristics of the individual, as well as (unobserved) characteristics of others living in the same state.
} 
individual's level of risk aversion could affect perceptions of security, by controlling for whether individuals have ever disclosed online their bank account number, their mother's maiden name, or their social security number. Third, we also control for a proxy for financial risk aversion, which captures whether an individual has declared bankruptcy. Our findings remain unchanged and are consistent with recent research showing that the media influence consumers' perceptions of security of payment instruments and ultimately their payment behavior (Kosse 2013a, Greene and Stavins 2016). ${ }^{3}$

To test whether our results are driven by social spillovers rather than reflection or other contextual factors, we exploit a unique exogenous shock available in the SCPC that directly affects a consumer's friend or relative significantly changes the consumer's own perception. To do this, we use the incidence of identity theft on a close friend of a consumer (as an exogenous shock that could affect security perceptions of a person's closest friends), while leaving the person unaffected. We find that a consumer whose close friend was a victim of identity theft tends to decrease his perception of payment security, which suggests the presence of social spillovers.

Finally, we examine whether social spillovers of security perceptions directly affect behavior, measured as the adoption and use of payment instruments. We find some significant, but small, spillover network effects: contemporaneous average perception of security at the state level tends to increase the adoption of checks, credit cards, and online banking bill payment (OBBP), when controlling for own lagged perception. As for use, contemporaneous state average perception of security is associated with higher use of debit cards and OBBP. As a robustness check, we restrict our sample to new adopters of payment instruments (that is, those who were nonadopters during the previous year), but find only mild evidence of the influence of social spillovers on payment behavior: contemporaneous average perception of security at

\footnotetext{
${ }^{3}$ As noted above, an influence of media is not necessarily the same as an influence of peers, although the issue is blurred by the presence of social media. In general, however, learning from direct contacts should be distinguished from learning from widely dispersed media. Our findings could be consistent with both effects.
} 
the state level seems to only affect the likelihood of becoming a new adopter of checks and OBBP.

Our findings provide new evidence that security assessments are likely to be influenced by factors beyond the socio-economic characteristics of payment users. To the best of our knowledge, we are the first to study how individual behavior is affected by social spillovers (peers' perceptions of security) in the context of the safety of payment instruments. The results

suggest that policymakers attempting to understand and influence perceptions of security need to take into consideration social norms for security perceptions.

The paper is organized as follows: Section 2 reviews the relevant literature related to security. Section 3 describes the data and econometric techniques. Results are reported in Section 4. Section 5 tests whether a consumer's peers' perceptions of payment security have an effect on the consumer's own payment behavior, and the final section summarizes the main conclusions.

\section{Literature review}

The literature on the effects of perceptions of security on payment behavior is not very extensive and the evidence is not conclusive (Rysman 2010). In regressions of payment adoption and use, the perceived security of a payment method was found to be significant in some cases, although typically less important than other characteristics of payment methods, such as ease of use or cost (Koulayev et al. 2016, Schuh and Stavins 2010, 2013, 2015b, Ching and Hayashi 2010). However, some work has found that external perceptions of risk may also influence how consumers pay. Kosse (2013a) finds that media coverage, such as newspaper articles on fraud, significantly affects debit card use in the very short term (the effect lasts only one day). Greene and Stavins (2016) find that people who assessed the security of debit cards after the Target breach was announced by the media in late 2013 rated the security of debit cards lower than those who assessed it before the breach was announced. Kosse (2013b) shows that consumers' payment preferences are strongly affected by their perceptions of safety, which in turn are 
primarily influenced by views on the probability of possible safety incidents occurring when using or carrying a payment instrument. Arango and Taylor (2009) show that perceived risk affects the choice of payment method, and Cope et al. (2013) find that consumers who consider mobile banking unsafe are less likely to adopt it. Kahn and Liñares-Zegarra (2015) show that experiencing identity theft or knowing someone who has experienced it influences how consumers pay. ${ }^{4}$ Consumer behavior in terms of privacy issues has been found to be affected both by endogenous factors (for example, subjective preferences) and by exogenous factors (for example, changes in privacy settings in user interfaces such as Facebook) (Acquisti et al. 2015).

Consumers may adjust their perceptions based on their peers' views. This kind of spillover effect has been widely explored in the context of social networks, since it may impact a wide array of economic and financial behavior (Miller 2015). For example, Fay et al. (2002) and Han and Li (2007) find that households are more likely to file for bankruptcy if they are located in a geographical area (for example, district or U.S. state) that had a higher filing rate in the previous year. Hong et al. (2004) find that social households - those that interact with their peers-are substantially more likely to invest in the stock market than non-social households. Duflo and Saez (2003) find that social network effects influence whether or not people invest in retirement plans, because individuals learn from others. Guiso et al. (2013) find that exposure to other people who strategically defaulted on their mortgages increases the individual's own propensity to default strategically.

Most of the papers cited here examine the effect of spillovers on actual behavior. In contrast, we examine the effect on perceptions, which in turn have also been found to affect real behavior. The perceptions of security measure the likelihood of either a financial/monetary loss, or the loss of personal information. We are attempting to measure whether and how people converge their perceptions, as opposed to their actual behavior, which the other papers cited here measure. While the mechanism through which the effect occurs may be different, the end result is the same: people change their behavior as a result of their peers' views.

\footnotetext{
${ }^{4}$ For a discussion related to this topic, see Hayashi and Sullivan (2013), Furletti and Smith (2005), and Sullivan (2010).
} 
Network externalities in payments have typically been analyzed only on the supply side (Gowrisankaran and Stavins 2004), where providers of payment services, such as banks, are more likely to start providing services when other banks located in their area do so. But network externalities can also exist on the demand side in the context of the perceptions of security, where people are more likely to adjust their own perceptions based on what other people's perceptions are. Hence, consumers may learn about security risks from the traditional media, as Kosse (2013a) finds, or from social media and other informal sources of information. Katz and Shapiro (1994) discuss the dynamics of consumer adoption decisions in the presence of network effects.

More recently, Mikhed and Vogan (2015) have looked into other ways the consumer may react to data breaches and identity theft, such as protecting her credit file by purchasing insurance and credit monitoring services, and have captured the consumer's reaction to environmental changes in the payment market. These authors find that consumers directly exposed to the data breach event responded by acquiring fraud protections available to them. The majority of consumers (individuals not directly affected by the breach), however, seriously considered fraud protection services only after they had formed a strong belief that their personal information had been compromised. Those authors also examined how local media attention to the issue of data breaches and identity theft may affect individuals and whether it may increase the effect of cybersecurity accidents. Their results suggest that news on identity theft and personal information security prompted some consumers to increase their protections independent of the breach, although the independent effect of the news was small.

In this paper we test whether consumers' perceptions of security are influenced by their peers' perceptions, whether because of the shared sources of information (the "correlated effect" mentioned above), or because of a direct effect through interactions -in person or on social media - with their peers. 


\section{Data}

We use panel data consisting of the 2008-2014 annual waves of the Survey of Consumer Payment Choice (SCPC). The SCPC is developed by the Consumer Payments Research Center (CPRC) of the Federal Reserve Bank of Boston and administered annually to a representative sample of the adult U.S. population. The survey data used here include individual-level variables on payment choice from 2008 to 2014, including adoption and use of nine common payment instruments, and assessments of payment characteristics. A detailed description of the data can be found in Schuh and Stavins (2014, 2015a).

Payment behavior is measured at the individual consumer level. Each year, a respondent is asked about his or her adoption and use of each payment instrument, and about his assessment of the characteristics of every payment instrument, regardless of whether the person has that instrument or not. The characteristics include acceptance, setup, cost, convenience, records, and security. The SCPC provides demographic information on age, gender, race, highest education level attained, marital status, ethnicity, nationality, and geographic region, as well as information on labor force status, household income, and the degree of financial responsibility within the household for every respondent. All the SCPC data are available to the public free of charge after the official results are published. ${ }^{5}$ Descriptive statistics of the main demographic variables used in our empirical models are provided in Table 1.

The SCPC provides consistent series of security perceptions on six payment instruments: checks, debit cards, credit cards, stored value cards, online banking bill payments (OBBP), and bank account number payments (BANP). ${ }^{6}$ Our key independent variable is the self-reported assessment of security. This variable rates the security of each payment method against

\footnotetext{
${ }^{5}$ See http://www.bostonfed.org/economic/cprc/data-resources.htm for the available data.

${ }^{6}$ An online banking bill payment (OBBP) is an electronic payment made directly from the customer's bank account to a vendor via her bank's online banking website. A bank account number payment (BANP) is a payment made by providing the customer's bank account number to a third party, such as her employer or a utility company.
} 
permanent financial loss or unwanted disclosure of personal information under the assumption that a payment method has been stolen, misused, or accessed without the owner's permission. The raw variable of security is coded on a Likert scale from 1 (very unsafe) to 5 (very safe). ${ }^{7}$ Table 2 reports statistics related to variation over time of perceptions of security within and between U.S. states. The numbers show a higher variation within states than between states, suggesting heterogeneity in perceptions of security at the state level. However, because there is substantial variation in the perceptions of security within and between states, we incorporate both in our model below.

The payments data are supplemented with state-level annual data on crime rates, for both violent and property crime, as well as with fraud and identity theft data from the Federal Trade Commission's (FTC) Consumer Sentinel Network. ${ }^{8}$ The latter is a database of consumer complaints available only to law enforcement. The database includes complaints reported directly to the FTC, some federal agencies, some state law enforcement organizations, and some non-governmental organizations. The FTC report splits the complaints into two categories: identity theft and fraud. The complaints are then organized by the state of residence of the complainant, and data are reported as the incidence of complaints per 100,000 residents in the given state.

\section{Model}

\section{a. Identification strategy and baseline model}

Our identification strategy attempts to address the main challenges described by Manski (1993, 2000) to identify a causal relationship between individuals and their peers: (i) endogenously formed peer groups, (ii) the reflection problem and reverse causality and (iii) evidence of social

\footnotetext{
7 Assessments of security are available for all surveyed individuals (even nonadopters assess payment characteristics).

${ }^{8}$ The violent and property crime data are from http://www.ucrdatatool.gov/Search/Crime/State/StatebyState.cfm and are only available for the period 2008-2012. The FTC fraud and identity theft data can be found at https://www.ftc.gov/enforcement/consumer-sentinel-network/reports.
} 
interactions. First, the design of the Survey of Consumer Payment Choice (SCPC) helps to mitigate concerns about self-selection since the sampling design of the SCPC relies on avoiding sorting of equals within states in order to achieve a nationally representative and diverse sample of the population. This in turn allows us to work with exogenously created state-level groups of individuals. ${ }^{9}$ Second, there is one important feature in our empirical setting which helps overcome concerns with the reflection and simultaneity problem. We exploit the panel nature of the data to track individuals throughout their time span in the panel to examine their payment-behavior patterns. This approach allows us to focus on the effect of others' perceptions in year $t$ on the transition in year $t+1$. A more detailed discussion is provided in subsection 4.C below. Finally, we use a few tests to provide evidence that peer groups have influential social interactions: (i) sociability of individuals (more-social individuals are more likely to be directly affected by others' behavior), (ii) age (younger people are more likely to be affected by social media) and, (iii) presence of an exogenous shock to security perception that has affected a person's friends (identity theft). A detailed discussion on sociability of individuals is provided in subsection 4 . D below.

We estimate a standard linear-in-means model where the difference between a consumer's perception of security and the average perception of the consumer's peers living in state $s$, excluding consumer $i$, in year $t-1$ is a determinant of the consumer's change in security perceptions from $t-1$ to $t$. We adapt the Ahern et al. (2014) model on peer influence to test for the existence of social spillovers on security assessments. Ahern et al. (2014) use survey results to measure peer effects on own risk aversion and trust. Although not used in the context of payments, that model also measures the effect of peer influence on perceptions and so is applicable here. ${ }^{10}$ The specification is as follows:

\footnotetext{
${ }^{9}$ In addition, transition probabilities (i.e. moving from one state to other over the time) of the population have been relatively low in our sample over the period of 2008 to 2014. Therefore, the problem of individuals self-selecting into a particular U.S. state do not seem to be an important issue in our sample.

${ }^{10}$ Although we use a similar econometric specification to the one in Ahern et al. (2014), our empirical identification strategy differs from theirs as described in the previous paragraph. In particular, Ahern et al. (2014) exploit random assignment of MBA students to peer groups to establish peer effects among their students. They use attitudes from
} 


$$
\begin{aligned}
& \Delta S E C_{i j s t}=\alpha+\beta_{1}\left(S E C_{i j s, t-1}-\overline{S E C}_{-i, j s, t-1}\right)+\beta_{2}\left(\overline{S E C}_{-i, j s, t-1}-\overline{S E C}_{j, t-1}\right)+ \\
& \theta X_{i s t}+\lambda_{t}+\gamma_{j}+\varepsilon_{i j s t},
\end{aligned}
$$

where $S E C_{i j s t}$ is the perception of security of consumer $i$ living in state $s$ in year $t$ for payment method $j$, measured on a scale from 1 (very unsafe) to 5 (very safe).

$S E C_{i j s, t-1}$ is the perception of security of consumer $i$ living in state $s$ in year $t-1 ; \overline{S E C}_{-i, j s, t-1}$ is the average perception of security of all people living in state $s$ in year $t-1$, excluding consumer $i$.

$X_{\text {ist }}$ is a set of control variables (age, education, income, race, gender, marital status, geographic region, nationality, labor force status) for individual $i$ residing in state $s$ in year $t$.

$\lambda_{t}=1$ if year is $t, 0$ otherwise.

$\gamma_{j}=1$ if payment instrument is $j, 0$ otherwise (a set of dummy variables), where $j=\{$ checks, debit cards, credit cards, stored value cards, OBBP, BANP $\}$.

Therefore, $\triangle S E C_{i j s t}$ is the change in one's own perception of security from $t-1$ to $t, S E C_{i j s, t-1}-$ $\overline{S E C}_{-i, j s, t-1}$ is the lagged difference between one's own perception of security and the state average, and $\overline{S E C}_{-i, j s, t-1}-\overline{S E C}_{j, t-1}$ is the lagged difference between the state average and the national average. The coefficient $\beta_{1}$ is the degree of adjustment in one's own perception of security as a result of the measured divergence from the state average, and the coefficient $\beta_{2}$ is the degree of adjustment in one's own perception of security as a result of the measured divergence between the state average and the national perception of security. Therefore, if a person's views are very different from those living around him, and if the perceptions of those living in his state are very different from the perceptions of the rest of the country, he might be more likely to change his perceptions in the following period.

the students prior to the start of the MBA program to estimate a causal relationship between the predetermined attitudes of a person's peers and the person's own attitudes after a year in the MBA program. Finally, they use selfreported friendship and professional contacts to verify that students have influential social interactions. 
This regression captures the change over time in the perceptions of each consumer based on the similarity of her perceptions to her peers' average perception. A negative and statistically significant $\beta_{1}$ indicates positive social spillovers within a state, while a negative and statistically significant $\beta_{2}$ indicates positive social spillovers nationally. ${ }^{11}$ Hence, a consumer who reports that a particular payment instrument is safer (less safe) than her peers' average perception of its safety in $t-1$ might adjust her perceptions downward (upward). Survey wave dummies $\left(\lambda_{t}\right)$ are employed to control for shocks common to all consumers in our sample, and payment instrument dummies $\left(\gamma_{j}\right)$ capture payment instrument fixed effects. ${ }^{12}$ Standard errors are clustered at the individual level across all our models to account for the correlation of errors over time within the same individual.

\section{b. Responding to positive and negative opinions}

"Bad news travels fast," so negative opinions are likely to spread faster than positive opinions and ultimately affect consumer perceptions. If a consumer already has a more secure assessment of a payment instrument than the average assessment/opinions of her peers $\left(S E C_{i, s, t-1} \geq \overline{S E C}_{-i, s, t-1}\right)$, we would expect the downward adjustment on her perceptions to be more powerful. Alternatively, a consumer with a riskier view than that of his peers $\left(S E C_{i, s, t-1}<\right.$ $\left.\overline{S E C}_{-i, s, t-1}\right)$ might adjust his perceptions upward, but presumably more gradually. In order to test whether this is the case, we estimate an interaction model that allows for the possibility of heterogeneity in the "measured divergence from the peers' perceptions" coefficient such that: ${ }^{13}$

\footnotetext{
${ }^{11}$ As mentioned above, the effect could arise from the diffusion of information used to form perceptions.

12 The data suggest that mean reversion is unlikely to explain our results, as the variation over time of the perceived riskiness of payment instruments does not seem to follow a clear pattern, so any external factors are likely to have affected perceptions in a systematic way. Figure A1 and Table A1 in the appendix illustrate variation in the perception of security, both across states and over time within a state, based on credit card security ratings. The map in Figure A1 shows a ranking of states based on perceptions of security of credit cards: 1 represents states in the lowest 20th percentile of the distribution (very risky) and 5 represents states in the top 20th percentile of the distribution (very safe). The high perceived risk category is highlighted in dark red, and the low perceived risk category is highlighted in pale pink. Table A1 shows that there is a substantial amount of variation in the relative security perception over time.

${ }^{13}$ See the appendix for the details of the transformation of our base specification. We have omitted the state minus national difference from this equation in the paper for simplicity, although it is included in the regression.
} 
$\Delta S E C_{i j s t}=\alpha+\delta_{1} N E G+\delta_{2}\left(S E C_{i j s, t-1}-\overline{S E C}_{-i, j \mathrm{j} s, t-1}\right)+\delta_{3}\left[\mathrm{NEG} *\left(S E C_{i j s, t-1}-\overline{S E C}_{-i, \mathrm{js}, t-1}\right)\right]+$

$\theta X_{i s t}+\lambda_{t}+\gamma_{j}+\varepsilon_{i j s t}$.

Equation (2) can be rewritten as follows (see the appendix for the details on this transformation):

$\Delta S E C_{i j s t}=\alpha+\delta_{4} N E G+\delta_{5}\left[N E G *\left(S E C_{i j s, t-1}-\overline{S E C}_{-i, j s, t-1}\right)\right]+\delta_{6}\left[P O S *\left(S E C_{i j s, t-1}-\right.\right.$

$\left.\left.\overline{S E C}_{-i, j s, t-1}\right)\right]+\theta X_{i s t}+\lambda_{t}+\gamma_{j}+\varepsilon_{i j s t}$,

where $\triangle S E C$ is individual $i$ 's change in the perception of the security of payment instrument $j, \alpha$ is the constant term, NEG is a dummy variable capturing whether a consumer perceives that a payment instrument is riskier than her peers' views in $t-1$, and POS is a dummy variable capturing whether a consumer perceives that a payment instrument is safer than her peers' views of that payment instrument in $t-1$.

$N E G *\left(S E C_{i j s, t-1}-\overline{S E C}_{-i, \mathrm{j} s, t-1}\right)$ and $P O S *\left(S E C_{i j s, t-1}-\overline{S E C}_{-i, \mathrm{js}, t-1}\right)$ represent the interaction terms between the two groups and the measured divergence from the peers' perceptions indicator, and $\varepsilon$ is the error term. Based on the above observations, we test the extent to which a consumer's perceptions of security are influenced by good or bad opinions about the security of payment instruments from her peers $\left(\mathrm{H}_{0}: \delta_{5}=\delta_{6}\right)$. A rejection of the null hypothesis would provide support for this hypothesis. Equation (3) is estimated via OLS with robust standard errors clustered at individual level. ${ }^{14}$

\section{c. Reflection vs. spillovers}

Manski (1993) defined "reflection," to indicate a situation where the same behavior is observed among members of the population but it is not clear whether the behavior of some individuals is influencing the behavior of others. To state it another way, the term "reflection" in this

\footnotetext{
${ }^{14}$ The results remain unchanged when standard errors are clustered at the state level rather than at the individual level.
} 
context denotes that the behavior of a person in a group resembles or reflects the behavior of others in his group but is not caused by that behavior.

It is difficult to separate the contemporaneous and reciprocal influences of others on an individual from the influence of the individual on the others. Manski (1993) finds that the only way to determine whether there is causality in behavior (rather than just reflection) is to have information specifying the composition of the reference groups. If this information is available, social spillovers may be inferred based on the relationship between the variables defining the reference groups and those directly affecting the outcomes. Determining whether there is causality or only correlation in behavior is difficult, and is more likely to be possible if the variables defining the reference groups and those directly affecting the outcomes are moderately related in the population.

The reflection problem primarily affects cross-sectional models (Manski 1993) and this causes the regressors to be linearly dependent, and no identification is possible. There is one important feature in our empirical setting that helps overcome concerns with the reflection and simultaneity problem. We use the panel nature of the data to track individuals throughout their time span in the panel to examine their payment-behavior patterns. This approach allows us to focus on the effect of others' perceptions in year $t$ on the transition in year $t+1$. The reflection problem is therefore less severe, since others' perceptions are already determined at the time of the transition from $\mathrm{t}-1$ to $\mathrm{t}$. Hence, others' perceptions of security are predetermined with respect to the subsequent perception of security of the individual instead of being jointly contemporaneously determined and may break the reflection problem. Other studies such as Cingano and Rosolia (2012), Schmutte (2015), and Smith et al. (2015) have also used a similar time-sequencing argument to address the reflection problem. ${ }^{15}$

\footnotetext{
15 An alternative solution to address the Manski's reflection problem relies on the use of instrumental variable techniques. In our case, it requires an instrument that is correlated with the divergence between one's own security rating and peers' average rating but does not have a direct impact on one's own security rating. We use as instrument an indicator variable capturing whether a respondent was born in another state from his current state of residence, and therefore might have priors that are different from his peers, but it is unlikely that the priors affect the change in
} 


\section{d. Sociability of the individuals}

If social network effects are the driving force in affecting one's own perception of payment security, we might also expect that more-sociable individuals would converge more quickly to their peers' views, as they interact with others more, and therefore have more opportunities to learn what others think, than those who are less sociable. We test this hypothesis by using data from the RAND American Life Panel to proxy for social interaction between individuals. We focus on a variable capturing sociability: "How often do you get together with [your neighbors] just to chat or for a social visit?" Based on the answer we classify the intensity of social interaction as $\mathrm{HIGH}=1$ if more than one time (which is the median value of the distribution) and $\mathrm{LOW}=0$ if one time or 'almost never' or 'never' get together. We estimate an interaction model similar to the positive and negative views model above, as follows:

$$
\begin{aligned}
& \Delta S E C_{i j s t}=\alpha+\vartheta_{1} * L O W+\vartheta_{2}\left[L O W *\left(S E C_{i j s, t-1}-\overline{S E C}_{-i, j s, t-1}\right)\right]+\vartheta_{3}\left[H I G H * \left(S E C_{i j s, t-1}-\right.\right. \\
& \left.\left.\overline{S E C}_{-i, j s, t-1}\right)\right]+\theta X_{i s t}+\lambda_{t}+\gamma_{j}+\varepsilon_{i j s t} .
\end{aligned}
$$

\section{Results}

\section{a. Social spillovers}

Table 3a reports regression results of estimating equation (1) using OLS. We use cluster-robust standard errors at the individual level to account for any serial correlation within individuals over time. The numbers reported in the table are the marginal effects based on normalized perceptions of security. Therefore, the results are interpreted as the effect of a onestandard-deviation change in the divergence from the peers' average perception. ${ }^{16}$

We estimated equation (1) for each payment instrument $j$ separately, but could not reject pooling all the payment instruments. Therefore, Table 3a and most of the subsequent tables

her own perceptions as they are already reflected in the perceptions. Results also support our findings about the existence of social spillovers and are available from the authors upon request.

${ }^{16}$ See Table A2 in the appendix for the degree of divergence from the peers' standard deviations. 
report the results for all payment instruments. To account for the variance within and between states, the model includes the divergence of individual $i$ 's perceptions of payment method $j$ from the average perception in state $s$, and the divergence from the average perception in state $s$ from the national average perception. Note that all the state-level averages exclude individual $i$ in order to measure the external effects of one's peers' perceptions on one's own perceptions (denoted as $-i$ in the model).

The results suggest the presence of significant social spillovers in payment perceptions. ${ }^{17}$ The effect of the degree of divergence from regional (state) average spillovers is greater than the effect of the degree of the divergence between state and national averages, suggesting that consumers are more likely to interact with and/or get information from peers who are located closer to them. However, both within-state and between-states spillover effects are statistically significant. Table $3 \mathrm{~b}$ shows the elasticities derived from the base model reported in Table 3a. The interpretation of the results is as follows:

- A 10 percent increase in the distance between $i$ 's security rating for payment $j$ and the average rating of $i^{\prime}$ s peers' living in state $s$ in $t-1$ will result in a 7.0 percent convergence in $i^{\prime}$ s rating in the next period.

- A 10 percent increase in the degree of divergence between the average rating in $i$ 's state for payment $j$ and the national average rating in $t-1$ will result in a 6.84 percent convergence in $i$ 's rating next period.

Therefore, consumers converge their perceptions of the security of payment instruments based both on the perceptions of others living in their state and on the perceptions of others outside their state.

\footnotetext{
17 As a robustness check, we use fixed effect models to investigate changes in perceptions after controlling for any time-invariant characteristics of the individual and her peers. However, since the dependent variable in the regressions is the change in security perception, the individual fixed effects are less intuitive to interpret, as they would be controlling for trends in individual changes in security perceptions. The results remain unchanged, and estimation results are available from the authors.
} 
Table 4 extends the model reported in Table 3a by including exogenous risk measures: state-level crime rates in the state of residence of consumer $i$, a proxy for the individual's risk aversion measured as the disclosure online of sensitive personal information by the consumer (social security number, bank account number, mother's maiden name), and the individual's financial risk-taking behavior, measured by whether or not the individual has ever been involved in a bankruptcy process. All of these measures could influence the individual's perception of the security of any payment instrument. ${ }^{18}$ Including these exogenous variables in the model allows us to test whether the perceptions of security are in fact capturing other effects. We find that after controlling for each of these factors, the main results remain unchanged. None of the factors seem to affect the perceptions of security. ${ }^{19,20}$ Convergence to national-level perceptions was omitted for simplicity, but adding it to the models did not alter our findings.

\section{b. Positive and negative opinions}

It could be argued that negative opinions are likely to spread faster than positive ones, so we would expect a stronger adjustment downward if consumers are more positive than their peers in their perception of the security of a payment instrument. If consumers' perceptions are more negative than those of their peers, they may also adjust, but presumably more gradually. Results in Table 5 separate positive deviation of a consumer's average perception of security from the regional average and negative deviation of a consumer's average perception of security from the regional average (see equation (3) above). Our results suggest that social spillovers are present in both cases-when a consumer's perception is lower and when it is

\footnotetext{
${ }^{18}$ Types of crimes included in the crime rate are: (i) Violent crimes: murder, forcible rape, robbery, aggravated assault; (ii) Property crimes: burglary, larceny-theft and motor vehicle theft. Data are measured on a state level in per capita terms. The FTC data include fraud and identity theft complaints.

${ }^{19}$ We checked the result that state-level crime does not affect the change of perceptions of security with a correlation analysis between average perceptions of individual payment instruments and average crime indicators at the state level (see Table A3 in the appendix). There is a negative correlation (as might be expected), but the correlation is very low. In other words, perceptions seem to capture some of the safety concerns related to crime, but the impact of crime on perceptions is marginal.

${ }^{20}$ Similar results were obtained using a fixed effects model. Results are available from the authors.
} 
higher than average: both $\delta_{5}$ and $\delta_{6}$ are statistically significant, and the hypothesis that positive and negative deviations have the same effect on convergence in perceptions cannot be rejected.

\section{c. Different degrees of social interaction}

As an extension to our previous analysis (see equation (4) above), we test whether moresociable individuals tend to converge more quickly to the state average. Based on a variable capturing the intensity of social interactions by individuals in our sample, we find that individuals with a higher level of social interactions tend to adjust their perceptions of security more quickly $\left(\vartheta_{3}\right.$ is greater than $\vartheta_{2}$ in absolute value), although the difference is not statistically significant. Results are reported in Table 6. These results should be interpreted with caution, because the data on sociability are available only for 2012.

A potentially important transmission mechanism for the spillover effects is social media. Because younger people are more likely than older people to be connected via social media, we tested whether the spillover effects are stronger for younger people. We split the sample and estimated the base model separately for people under age 35 and for people over age 55. We also estimated the model separately for state effects, census region effects, and national effects. As the results in Table 7 show, the social spillover effects are stronger for the younger cohort in every specification, indicating that younger people are more likely to converge to the average perception of their peers, a result that seems intuitive, given the effect of social media. This relationship between age and social spillovers holds for the national, census region, and statelevel models.

Separating social spillovers and contextual effects is challenging. According to Ahern et al. (2014), “...To do so [separating social spillovers and contextual effects] requires the highly unusual occurrence of an exogenous shock to the attitudes of a person's peers, while leaving the person unaffected..." (page 3215). As an additional test to provide more corroborating evidence about the existence of social spillovers on payment perceptions, we use a proxy to capture an exogenous shock that could affect the security perceptions of a person's closest friends, while 
leaving the person unaffected. Using survey responses from the SCPC panel, we build a variable that indicates whether a close friend of an individual has been the victim of identity theft. This variable measures the extent to which a negative security shock of a close friend could influence individual perceptions. We follow Kosse (2013b) and use a random-effects ordered logistic model. The dependent variable is the measure of perception of security ranging from 1 to 5, where a higher rating corresponds to a higher level of perceived security.

The model is estimated separately for each payment instrument, because the effects of an identity theft occurring to a friend vary by type of payment. ${ }^{21}$ The results in Table 8 show that a consumer whose close friend had been a victim of identity theft tends to decrease his perception of payment security for some payment instruments. In particular, marginal effects for our key variable "ID Theft" suggest that the security perception of checks, debit cards, and BANP are negatively correlated with negative security shocks occurring to a friend. For example, knowing a victim of identity theft tends to reduce the probability of assessing checks as "Very secure" or "Secure," and increases the probability of assessing checks as "Risky" or "Very risky." Our results support our previous findings indicating that social influence seems to matter when individual perceptions are formed. This is an indication that our results are not driven by reflection or other contextual effects.

Interestingly, the effect of identity theft on a friend is significant for payment instruments that are directly connected to a person's bank account. The reason could be that bank accounts are more vulnerable to identity theft, in contrast with credit cards, which are more likely to be stolen, lost, or mishandled in terms of the credit card number itself, but not in terms of one's user identity data being stolen.

\footnotetext{
${ }^{21}$ We are especially interested in security assessments of payment cards, because the Federal Reserve Payments Study shows that the fraud rate for payment cards is much higher than the fraud rate for check or ACH (Federal Reserve System 2013). In addition, larger payment card fraud cases typically receive considerable publicity, making consumers more aware of those cases compared with check- or ACH-related cases.
} 


\section{d. Correlation of perceptions across payment instruments}

To test whether people tend to reduce/improve their security assessments of all other payment methods jointly even when there is an external shock that directly affects only one payment instrument, we tested whether changes in perceptions are correlated across payment instruments. Correlation coefficients indicate that changes in security ratings from year to year are not highly correlated across different payment instruments. However, in regressions of the change in the security rating of a given payment instrument on changes in the security rating of all other payment instruments, most of the coefficients are positive and highly significant (the results are available from the authors). Therefore, a change in the rating of one instrument is a strong predictor of changes in the ratings of other instruments. Year effects, as measured by year dummy coefficients, are also significant. These results suggest that people form their perceptions of security for all payment instruments simultaneously, and may therefore converge all their perceptions to those of their peers, even if they learn about perceptions pertaining directly to only a single payment instrument.

\section{e. Role of geography}

In the main specification (equation (1), Tables 3a and 3b), both the state-level effects and the national-level effects are included. In addition to the pooled model used as our main specification, we also estimated the model separately for various geographic regions: [1] only the divergence from the state average was included, [2] only the divergence from the census region average was included, and [3] only the divergence from the national average was included. We find that if entered separately in regressions, national spillover effects are stronger than census region effects, which in turn are stronger than state-level effects. While all the spillover effects are statistically significant, the magnitude increases for broader geographic regions. This is because geographic effects are likely to be nested: the state effects are nested in the census region effects, which in turn are nested in the national effects. 
It is feasible that people living in larger states (in terms of their geographic area) would be more isolated from other states, and therefore would exhibit a larger degree of convergence to the perceptions of others living in their state. In other words, a large state like Texas may constitute a strong network, while a small state like Delaware may be more tied to other states in the region and therefore create a weaker network for social spillover effects. We tested whether an individual's deviation from his regional average is affected by the size of his state and by the distance from other states. To test this, we included a measure of the area of each state (raw and in log form) and a measure of the distance from the neighboring states in the main specification. However, neither the area nor the distance measures were significant predictors of the deviation from the state average. The size of the state is not a significant factor overall, and the main relationship between an individual's change in perception and the deviation from the regional average holds even when we control for it.

\section{f. Robustness checks}

As a robustness check, we performed a battery of additional tests to complement the main results. Table 9 shows the results of three models estimated under alternative specifications of the original model (equation (1)). Model 1 shows the results without demographic or other control variables, as most of them were found to be statistically insignificant in Table 3a. Model 2 includes the demographic and other control variables, but omits the year effects. Model 3 excludes all demographic and control variables, as well as the year dummies. The effect of the divergence from the average state perception and the effect of the divergence between the state and the national average for all three models remain almost exactly the same as in the original specification (Table 3a), and the adjusted $\mathrm{R}^{2}$ remains unchanged.

\section{Social spillovers and payment behavior}

Above, we show that there is evidence for social spillovers, whereby others' perceptions of the security of payment instruments affect a consumer's own perception of security. In this section, we test whether others' perceptions of payment security have a direct effect on a 
consumer's payment behavior, in addition to any indirect effects of the consumer's perception of security on his or her own behavior. We measure payment behavior with two variables: the adoption of each payment instrument, and then the use of the payment instrument conditional on adoption. We apply the two-step Heckman methodology as in Schuh and Stavins (2010, 2013) and in Kahn and Liñares-Zegarra (2015) to estimate adoption and use of each payment instrument, but we include a consumer's peers' perception of security as an explanatory variable.

For each payment instrument, we estimate own adoption and use at time $t$ as a function of own perceptions (including security) at time $t-1$, and of the average perception of security of the consumer's peers at time $t-1$. Both own perceptions and others' perception are lagged, and therefore all are exogenous at time $t$. The majority of previous studies of the relationship between perception and payment behavior (including the ones cited here) have relied on concurrent surveys measuring both perceptions and behavior at time $t$. Consequently, there has been an uncertainty about the direction of causality: do perceptions influence consumer choice or are perceptions simply ex post rationalizations by consumers of their own payment behavior? We are able to exploit panel data on perception and consumer payment choice to show that perceptions elicited in one round of surveys have mild but significant effects on subsequent changes in behavior.

Table 10 shows the regression results. For the sake of brevity, we report only the coefficients of perceptions. Control variables follow Schuh and Stavins (2010) and include age, education, marital status, number of household members, ethnicity, race, gender, income, work status, degree of financial responsibility within the family, house ownership, number of other adopted payment instruments, and year dummies. We find some statistically significant, but small in magnitude, social spillovers effects: state averages of security perception have only a 
very mild direct effect on a consumer's behavior. Therefore, the spillovers affect payment behavior indirectly, through an effect on a consumer's own perceptions. ${ }^{22}$

\section{Conclusions}

Payment security is central to ensuring the smooth operation of payment systems. Changes in social environments, such as peers' views or opinions, could lead to changes in the way consumers perceive certain payment instruments in terms of security. Our results suggest that it could be the case that when a consumer's peers' perceived security of a particular payment instrument is high, that is, when they consider the payment instrument very safe, the consumer's own perception of the security of that payment instrument increases in the following period. The effect is strong - a 10 percent increase in the extent of the divergence in the consumer's security rating from that of her peers leads to a 7 percent change in her own security rating in the next period. In contrast, we find limited evidence of the impact of social spillovers on payment behavior (adoption and use), implying that the social spillovers of peers' perceptions affect one's own behavior only indirectly through the effect on own perceptions. The results remain robust to alternative models, specifications, and endogeneity concerns.

The results of this paper demonstrate that consumers' assessments of payment security can potentially be influenced by the opinions of others with whom they interact, whether through direct contact or through social media. This has interesting implications for the payment industry. For example, customers with negative perceptions toward certain (or new) payment instruments may alter their views about that instrument's security based on the social norms or the views of those with whom they interact, and this effect can be strengthened by the presence of social media, which are national in scope. The existence of such spillovers in

\footnotetext{
${ }^{22}$ As a robustness check, we also test the influence of state averages of security on the probability of being a new adopter in year $t$ (conditional on having been a nonadopter in year $t-1$ ). Results reported in Table A4 in the appendix suggest that state averages of security tend to increase the probability of being a new adopter of checks and OBBP, when controlling for one's own lagged perception. Because the survey questions related to stored value card (SVC) adoption changed in 2011, the negative effect on SVC adoption may not reflect the spillover effects, but instead may be caused by the changes in the questionnaire.
} 
payment markets could lead to positive or negative changes in the aggregate perception of security for the whole payment system and could ultimately affect the adoption and use of payment instruments. 


\section{References}

Acquisti, A., L. Brandimarte, and, G. Loewenstein. 2015. Privacy and human behavior in the age of information. Science 347: 509-514.

Ahern, K.R., R. Duchin, and T. Shumway. 2014. Peer effects in risk aversion and trust. Review of Financial Studies 27: 3213-3240.

Arango, C., and V. Taylor. 2009. The role of convenience and risk in consumers' means of payment. In: Discussion Papers. Bank of Canada

Borzekowski, R., and E.K. Kiser. 2008. The choice at the checkout: Quantifying demand across payment instruments. International Journal of Industrial Organization 26: 889-902.

Borzekowski, R., K.E. Kiser, and S. Ahmed. 2008. Consumers' use of debit cards: Patterns, preferences, and price response. Journal of Money, Credit and Banking 40: 149-172.

Bursztyn, L., F. Ederer, B. Ferman, and N. Yuchtman. 2014. Understanding mechanisms underlying peer effects: evidence from a field experiment on financial decisions. Econometrica 82: 1273-1301.

Cheney, J.S., R.M. Hunt, K.R. Jacob, R.D. Porter, and B.J. Summers. 2012. The efficiency and integrity of payment card systems: Industry views on the risks posed by data breaches. Economic Perspectives 36.

Ching, A.T., and F. Hayashi. 2010. Payment card rewards programs and consumer payment choice. Journal of Banking \& Finance 34: 1773-1787.

Cingano, F. and Rosolia, A. 2012. People I know: workplace networks and job search outcomes. Journal of Labor Econonomics, 30(2): 291-332.

Cope, A.M., A.M. Rock, and M.D. Schmeiser. 2013. Risk perception, risk tolerance and consumer adoption of mobile banking services. SSRN Working Paper No 2048565

Duflo, E., and E. Saez. 2003. The role of information and social interactions in retirement plan decisions: Evidence from a randomized experiment. The Quarterly Journal of Economics 118(3): 815-842 (August).

Fay, S., E. Hurst, and M.J. White. 2002. The household bankruptcy decision. The American Economic Review 92: 706-718.

Federal Reserve System. 2013. The 2013 federal reserve payments study. Federal Reserve System, Washington, D.C. 
Federal Reserve System. 2015a. Strategic plan 2016-19. Board of Governors of the Federal Reserve System (ed.). Federal Reserve System.

Federal Reserve System. 2015b. Strategies for improving the U.S. Payment system. Federal Reserve System.

Furletti, M., and S. Smith. 2005. The laws, regulations, and industry practices that protect consumers who use electronic payment systems: Credit and debit cards. Federal Reserve Bank of Philadelphia Discussion Paper.

Gowrisankaran, G., and J. Stavins. 2004. Network externalities and technology adoption: Lessons from electronic payments. RAND Journal of Economics 35: 260-276.

Greene, C., and J. Stavins. 2016. Did the Target data breach change consumer assessments of payment card security? Federal Reserve Bank of Boston Research Data Report No. 16-1.

Guiso, L., P. Sapienza, and L. Zingales. 2013. The Determinants of Attitudes toward Strategic Default on Mortgages. The Journal of Finance 68: 1473-1515.

Han, S., and W. Li. 2007. Fresh start or head start? The effects of filing for personal bankruptcy on work effort. Journal of Financial Services Research 31: 123-152.

Hayashi, F., and R. J. Sullivan. 2013. Fees, fraud and regulation: Forces of change in the payment card industry. In: Payments System Research Briefing

Hong, H., J.D. Kubik, and J.C. Stein. 2004. Social interaction and stock-market participation. The Journal of Finance 59: 137-163.

Kahn, C., and J. Liñares-Zegarra. 2015. Identity theft and consumer payment choice: Does security really matter? Journal of Financial Services Research 50(1): 121-159.

Katz, M.L., and C. Shapiro. 1994. Systems competition and network effects. The Journal of Economic Perspectives: 93-115.

Kosse, A. 2013a. Do newspaper articles on card fraud affect debit card usage? Journal of Banking $\mathcal{E}$ Finance 37: 5382-5391.

Kosse, A. 2013b. The safety of cash and debit cards: A study on the perception and behavior of dutch consumers. International Journal of Central Banking 9: 77-98.

Koulayev, S., M. Rysman, S. Schuh, and J. Stavins. 2016. Explaining adoption and use of payment instruments by U.S. consumers. RAND Journal of Economics 47(2): 293-325 (Summer).

Manski, C. F. 1993. Identification of endogenous social effects: The reflection problem. The Review of Economic Studies 60(3): 531-542. 
Manski, C. F. 2000. Economic Analysis of Social Interactions. Journal of Economic Perspectives, 14(3): 115-136.

Mikhed, V., and M. Vogan. 2015. Out of sight, out of mind: Consumer reaction to news on data breaches and identity theft. Philadelphia Fed's Research Department. Working Papers $15-42$.

Miller, M.M. 2015. Social networks and personal bankruptcy. Journal of Empirical Legal Studies 12: $289-310$.

Rysman, M. 2010. The changing retail payments landscape: What role for central banks. In: $A n$ international payment policy conference, chap. Consumer payment choice: Measurement topics. Federal Reserve Bank of Kansas City, pp. 61-81.

Schmutte, I. M. 2015. Job referral networks and the determination of earnings in local labor markets. Journal of Labor Economics, 33(1): 1-32.

Smith, S., Windmeijer, F., \& Wright, E. 2015. Peer effects in charitable giving: Evidence from the (running) field. The Economic Journal, 125(585): 1053-1071.

Schuh, S., and J. Stavins. 2010. Why are (some) consumers (finally) writing fewer checks? The role of payment characteristics. Journal of Banking $\mathcal{E}$ Finance 34: 1745-1758.

Schuh, S., and J. Stavins. 2013. How consumers pay: Adoption and use of payments. Accounting and Finance Research 2: 1-21.

Schuh, S., and J. Stavins. 2014. The 2011-2012 survey of consumer payment choice: Summary results. Federal Reserve Bank of Boston Research Data Report No. 14-1.

Schuh, S., and J. Stavins. 2015a. The 2013 survey of consumer payment choice: Summary results. Federal Reserve Bank of Boston Research Data Report No. 15-4.

Schuh, S., and J. Stavins. 2015b. How do speed and security influence consumers' payment behavior? Contemporary Economic Policy 1-19.

Stavins, J. 2013. Security of retail payments: The new strategic objective. In: Federal Reserve Bank of Boston Public Policy Discussion Paper No. 13-9.

Sullivan, R.J. 2010. The changing nature of U.S. card payment fraud: Industry and public policy options. Economic Review 95: 101-133. 
Table 1: Sample demographics

\begin{tabular}{|c|c|c|c|c|c|}
\hline Variable & Observations & Mean & Standard deviation & Minimum & Maximum \\
\hline Age & 13,165 & 50.38 & 14.97 & 16 & 93 \\
\hline Education: High school & 13,165 & 0.16 & 0.36 & 0 & 1 \\
\hline Education: Some college & 13,165 & 0.37 & 0.48 & 0 & 1 \\
\hline Education: College degree & 13,165 & 0.25 & 0.44 & 0 & 1 \\
\hline Education: Post-graduate studies & 13,165 & 0.19 & 0.40 & 0 & 1 \\
\hline Married & 13,165 & 0.64 & 0.48 & 0 & 1 \\
\hline Income: $\$ 25,000$ - $\$ 49,999$ & 13,133 & 0.25 & 0.44 & 0 & 1 \\
\hline Income: $\mathbf{\$ 5 0 , 0 0 0}$ - $\$ \mathbf{7 4 , 9 9 9}$ & 13,133 & 0.22 & 0.42 & 0 & 1 \\
\hline Income: $\$ 75,000$ - $\$ 99,000$ & 13,133 & 0.14 & 0.35 & 0 & 1 \\
\hline Income: over $\$ 100,000$ & 13,133 & 0.21 & 0.41 & 0 & 1 \\
\hline Male & 13,165 & 0.44 & 0.50 & 0 & 1 \\
\hline White & 13,164 & 0.85 & 0.36 & 0 & 1 \\
\hline
\end{tabular}


Table 2: Within and between state variations in security perceptions (2008-2014)

\begin{tabular}{|c|c|c|c|c|c|c|}
\hline Payment Instrument & Variation at state level & Mean & Std. Dev. & Min & Max & Sample \\
\hline Checks & $\begin{array}{c}\text { Overall } \\
\text { Between } \\
\text { Within }\end{array}$ & 3.02 & $\begin{array}{l}0.31 \\
0.17 \\
0.26\end{array}$ & $\begin{array}{c}2 \\
2.71 \\
2.11\end{array}$ & $\begin{array}{c}4 \\
3.49 \\
4.25\end{array}$ & $\begin{array}{c}\text { Number of States: } 49 \\
\text { Years: 2008-2014 }\end{array}$ \\
\hline Debit Cards & $\begin{array}{c}\text { Overall } \\
\text { Between } \\
\text { Within }\end{array}$ & 3.00 & $\begin{array}{l}0.35 \\
0.19 \\
0.29\end{array}$ & $\begin{array}{c}1 \\
2.40 \\
1.60\end{array}$ & $\begin{array}{c}4 \\
3.44 \\
3.98\end{array}$ & $\begin{array}{c}\text { Number of States: } 49 \\
\text { Years: 2008-2014 }\end{array}$ \\
\hline Credit Cards & $\begin{array}{c}\text { Overall } \\
\text { Between } \\
\text { Within }\end{array}$ & 3.21 & $\begin{array}{l}0.40 \\
0.21 \\
0.35\end{array}$ & $\begin{array}{c}2 \\
2.79 \\
1.57\end{array}$ & $\begin{array}{c}5 \\
3.81 \\
4.57\end{array}$ & $\begin{array}{c}\text { Number of States: } 49 \\
\text { Years: 2008-2014 }\end{array}$ \\
\hline Stored Value Cards & $\begin{array}{c}\text { Overall } \\
\text { Between } \\
\text { Within }\end{array}$ & 2.75 & $\begin{array}{l}0.41 \\
0.23 \\
0.34\end{array}$ & $\begin{array}{c}1 \\
1.64 \\
1.20\end{array}$ & $\begin{array}{c}4 \\
3.26 \\
4.28\end{array}$ & $\begin{array}{c}\text { Number of States: } 49 \\
\text { Years: 2008-2014 }\end{array}$ \\
\hline OBBP & $\begin{array}{c}\text { Overall } \\
\text { Between } \\
\text { Within }\end{array}$ & 3.30 & $\begin{array}{l}0.36 \\
0.24 \\
0.26\end{array}$ & $\begin{array}{c}2 \\
2.82 \\
2.33\end{array}$ & $\begin{array}{c}5 \\
4.12 \\
4.53\end{array}$ & $\begin{array}{c}\text { Number of States: } 49 \\
\text { Years: 2009-2014 }\end{array}$ \\
\hline BANP & $\begin{array}{c}\text { Overall } \\
\text { Between } \\
\text { Within }\end{array}$ & 2.64 & $\begin{array}{l}0.34 \\
0.16 \\
0.31\end{array}$ & $\begin{array}{l}1.67 \\
2.31 \\
1.72 \\
\end{array}$ & $\begin{array}{c}3.8 \\
3.03 \\
3.64 \\
\end{array}$ & $\begin{array}{c}\text { Number of States: } 49 \\
\text { Years: 2009-2014 }\end{array}$ \\
\hline
\end{tabular}

Note: Hawaii (HI), Puerto Rico (PR), and Wyoming (WY) were excluded from the sample because of the small number of usable observations. 


\section{Table 3a: An individual's changes in perceptions of security on divergence from the state and national averages (marginal effects)}

\begin{tabular}{|c|c|}
\hline & Dependent Variable: $\Delta S E C_{i j s t}$ \\
\hline$\overline{S S E C_{i, j, s, t-1}-\overline{S E C}_{-i, j s, t-1}}$ & $\begin{array}{c}-0.596 * * * \\
(0.01)\end{array}$ \\
\hline$\overline{S E C}_{j, s, t-1}-\overline{S E C}_{j, t-1}$ & $\begin{array}{c}-0.058 * * * \\
(0.004)\end{array}$ \\
\hline Age & $\begin{array}{l}0.006 \\
(0.00)\end{array}$ \\
\hline Education: High school & $\begin{array}{l}0.005 \\
(0.04)\end{array}$ \\
\hline Education: Some college & $\begin{array}{l}0.003 \\
(0.04)\end{array}$ \\
\hline Education: College degree & $\begin{array}{l}0.000 \\
(0.04)\end{array}$ \\
\hline Education: Post-graduate studies & $\begin{array}{l}0.000 \\
(0.04)\end{array}$ \\
\hline Married & $\begin{array}{l}-0.009 \\
(0.01)\end{array}$ \\
\hline Income: $\$ 25,000$ - $\$ 49,999$ & $\begin{array}{l}-0.002 \\
(0.02)\end{array}$ \\
\hline Income: $\$ 50,000-\$ 74,999$ & $\begin{array}{l}-0.000 \\
(0.02)\end{array}$ \\
\hline Income: $\$ 75,000-\$ 99,000$ & $\begin{array}{c}0.012 * * \\
(0.02)\end{array}$ \\
\hline Income: over $\$ 100,000$ & $\begin{array}{c}0.016^{* * *} \\
(0.02)\end{array}$ \\
\hline Male & $\begin{array}{c}0.038 * * * \\
(0.01)\end{array}$ \\
\hline White & $\begin{array}{l}-0.008 \\
(0.02) \\
\end{array}$ \\
\hline $\mathbf{N}$ & 44379 \\
\hline Year Fixed Effects & YES \\
\hline Payment Instrument Fixed Effects & YES \\
\hline F-test (Wald test) & $605.18 * * *$ \\
\hline Adjusted R-squared & 0.347 \\
\hline
\end{tabular}

Note: Marginal effects from OLS regressions, where the dependent variable is individual $i$ 's change in raw perception of security for payment $j$ from wave $t-1$ to wave $t . S E C_{i, j, s, t-1}-\overline{S E C}_{-i, j, s, t-1}$ is the difference between the individual's raw perception of security and average raw perception of security in the state of residence (regional).

$\overline{S E C}_{j, s, t-1}-\overline{S E C}_{j, t-1}$ is the difference between the average raw perception of security in the state of residence in wave $t-1$ and the national average in wave $t-1$. Variables are normalized so that coefficients represent the standard deviation changes for a one-standard-deviation-change in independent variables. Explanatory variables are individual $i$ 's characteristics, which are exogenous with respect to perceptions of security such as age, education, income, gender, and marital status. Standard errors clustered at individual and payment instrument level are in parentheses. Significance at the $5 \%$, and $1 \%$ level is indicated by $* *$ and $* * *$. 


\section{Table 3b: An individual's changes in perceptions of security by divergence from the regional and national averages (elasticities)}

The table below reports elasticities based on the results in Table 3a. The numbers can be interpreted as follows:

- A 10 percent increase in the distance between $i$ 's security rating for payment $j$ and $i$ 's peers' rating in $t-1$ will result in a 7.0 percent reduction in $i$ 's rating in the next period.

- A 10 percent increase in the distance between average rating in $i$ 's state for payment $j$ and the national rating in $t-1$ will result in a 6.84 percent reduction in $i$ 's rating next period.

Dependent Variable: $\Delta \ln \left(S E C_{i, j, s, t}\right) \approx$ percentage change in $i$ 's security perceptions of payment method $j$

\begin{tabular}{|c|c|}
\hline $\ln S E C_{i j s, t-1}-\ln \overline{S E C}_{-i, j s, t-1}$ & $\begin{array}{c}-0.700 * * * \\
(0.01)\end{array}$ \\
\hline $\ln \overline{S E C}_{-i, j s, t-1}-\ln \overline{S E C}_{j, t-1}$ & $\begin{array}{c}-0.684 * * * \\
(0.09)\end{array}$ \\
\hline$\overline{\mathbf{N}}$ & 44379 \\
\hline Year Fixed Effects & YES \\
\hline Control Variables & YES \\
\hline Payment Instrument Fixed Effects & YES \\
\hline F-test (Wald test) & $311.136^{* * *}$ \\
\hline Adjusted R-squared & $0 . .361$ \\
\hline
\end{tabular}

Note: Coefficients from OLS regressions, where the dependent variable is individual $i$ 's percentage change in raw perception of security from wave $t-1$ to wave $t$.

$\ln S E C_{i j s, t-1}-\ln \overline{S E C}_{-i, j s, t-1}$ is the difference in $\operatorname{logs}$ between individual $i$ 's raw perception of security and the average raw perception of security in the state of residence $s$ for payment method $j$. $\ln \overline{S E C}_{-i, j s, t-1}-\ln \overline{S E C}_{j, t-1}$ is the difference in logs between a state's average raw perception of security and the national average in wave $t-1$. Variables are normalized so that coefficients represent the standard deviation changes for a one-standard-deviation-change in independent variables. Explanatory variables are individual characteristics, which are thought to be exogenous to perceptions of security, such as age, education, income, and marital status. Standard errors clustered at individual and payment instrument level are in parentheses. Significance at the $5 \%$, and $1 \%$ level is indicated by $* *$ and $* * *$. 
Table 4: An individual's changes in perceptions of security by divergence from the regional averages, controlling for crime and the individual's risk behavior

\begin{tabular}{|c|c|c|c|c|c|}
\hline & \multicolumn{5}{|c|}{ Dependent Variable: $\Delta S E C_{i j s t}$} \\
\hline & $\begin{array}{c}\begin{array}{c}\text { Regional } \\
\text { crime per } \\
\text { capita }\end{array} \\
\end{array}$ & $\begin{array}{l}\text { Ever disclosed online: } \\
\text { Social Security Number }\end{array}$ & $\begin{array}{c}\text { Ever disclosed } \\
\text { online: Bank } \\
\text { Account Number } \\
\end{array}$ & $\begin{array}{l}\text { Ever disclosed online: } \\
\text { Mother's maiden name }\end{array}$ & $\begin{array}{c}\text { Declared } \\
\text { bankruptcy }\end{array}$ \\
\hline$S E C_{i j s, t-1}-\overline{S E C}_{-i, j s, t-1}$ & $\begin{array}{c}-0.580 * * * \\
(0.01)\end{array}$ & $\begin{array}{c}-0.576 * * * \\
(0.01)\end{array}$ & $\begin{array}{c}-0.576 * * * * \\
(0.01)\end{array}$ & $\begin{array}{c}-0.576 * * * * \\
(0.01)\end{array}$ & $\begin{array}{c}-0.574 * * * \\
(0.01)\end{array}$ \\
\hline Crime and Risk Behavior $r_{t-1}$ & $\begin{array}{r}0.004 \\
(.48)\end{array}$ & $\begin{array}{l}-0.003 \\
(0.01)\end{array}$ & $\begin{array}{c}0.015 * * * \\
(0.01)\end{array}$ & $\begin{array}{c}-0.010^{* *} \\
(0.01)\end{array}$ & $\begin{array}{l}0.008 \\
(0.03)\end{array}$ \\
\hline $\mathbf{N}$ & 37074 & 41203 & 41191 & 41180 & 40525 \\
\hline Year Fixed Effects & YES & YES & YES & YES & YES \\
\hline $\begin{array}{l}\text { Payment Instrument Fixed } \\
\text { Effects }\end{array}$ & YES & YES & YES & YES & YES \\
\hline Additional Controls & YES & YES & YES & YES & YES \\
\hline F-test (Wald test) & $656.9^{* * *}$ & $705.7 * * *$ & $705.5 * * *$ & $705.8 * * *$ & $687.0 * * *$ \\
\hline Adjusted R-squared & 0.336 & 0.331 & 0.331 & 0.331 & 0.330 \\
\hline
\end{tabular}

Note: Coefficients from OLS regressions, where the dependent variable is individual $i$ 's change in raw perception of security of payment method $j$ from wave $t-1$ to wave $t . S E C_{i j s, t-1}-\overline{S E C}_{-i, j s, t-1}$ is the difference between individual $i$ 's raw perception of security for payment instrument $j$ and the average raw perception of security in the state of residence $s$ (regional) or the country (national) in wave $t-1$. Variables are normalized so that coefficients represent the standard deviation changes for a one-standard-deviation-change in independent variables. Crime is measured per capita in the individual's state of residence. It includes: (i) Violent crimes: murder, forcible rape, robbery, aggravated assault; (ii) Property crimes: burglary, larceny-theft and motor vehicle theft. Risk behavior is a dummy variable that captures whether the individual is risk-averse by disclosing personal information on the internet (for example, social security number, bank account number, or mother's maiden name). The last control, "declared bankruptcy," also attempts to capture risky behavior from a financial perspective. Additional control variables includes characteristics that are thought to be exogenous to perceptions of security such as age, education, income, and marital status. Standard errors clustered at individual and payment instrument level are in parentheses. Significance at the 5\%, and $1 \%$ level is indicated by $* *$ and $* * *$. 


\section{Table 5: Influence of negative and positive news on changes in perceptions of} security

$$
\begin{aligned}
\Delta S E C_{i j s t}=\alpha+ & \delta_{4} N E G+\delta_{5}\left[N E G *\left(S E C_{i j s, t-1}-\overline{S E C}_{-i, j s, t-1}\right)\right] \\
& +\delta_{6}\left[P O S *\left(S E C_{i, j s, t-1}-\overline{S E C}_{-i, j s, t-1}\right)\right]+\theta X_{i s t}+\lambda_{t}+\gamma_{j}+\varepsilon_{i j s t}
\end{aligned}
$$

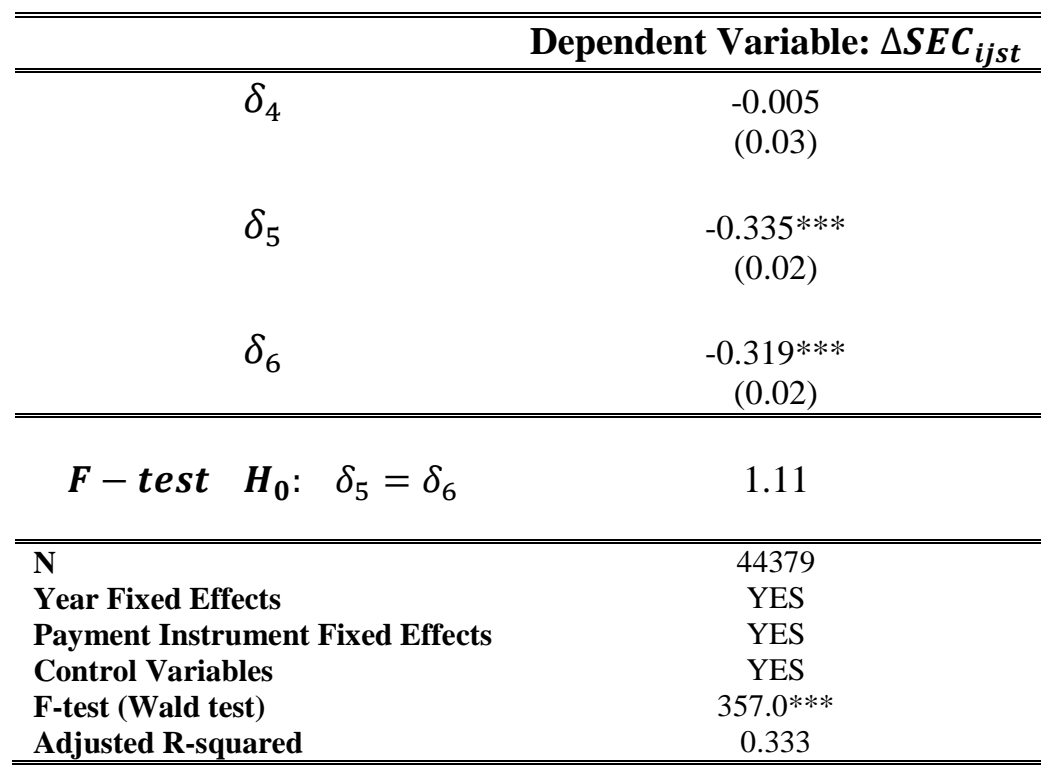

Note: Coefficients from OLS regressions, where the dependent variable is individual $i$ 's change in raw perception of security of payment method $j$ from wave $t-1$ to wave $t$. Variables are normalized so that coefficients represent the standard deviation changes for a one-standard-deviation-change in the independent variables. Standard errors clustered at individual level are in parentheses. Significance at the 5\%, and $1 \%$ level is indicated by $* *$ and $* * *$. 
Table 6: Influence of sociability on changes in perceptions of security

$$
\begin{aligned}
& \Delta S E C_{i j s t}=\alpha+\vartheta_{1} * L O W+\vartheta_{2}\left[L O W *\left(S E C_{i j s, t-1}-\overline{S E C}_{-i, j s, t-1}\right)\right]+\vartheta_{3}[H I G H * \\
& \left.\left(S E C_{i j s, t-1}-\overline{S E C}_{-i, j s, t-1}\right)\right]+\theta X_{i s t}+\lambda_{t}+\gamma_{j}+\varepsilon_{i j s t}
\end{aligned}
$$

\begin{tabular}{|c|c|}
\hline & Number of times get together with people (High/Low) \\
\hline$\vartheta_{1}$ & $\begin{array}{c}-0.004 \\
(0.04)\end{array}$ \\
\hline$\vartheta_{2}$ & $\begin{array}{c}-0.333 * * * \\
(0.03)\end{array}$ \\
\hline$\vartheta_{3}$ & $\begin{array}{c}-0.473 * * * \\
(0.02) \\
\end{array}$ \\
\hline F-test $\quad \boldsymbol{H}_{\mathbf{0}}: \vartheta_{2}=\vartheta_{3}$ & 0.18 \\
\hline $\mathbf{N}$ & 8589 \\
\hline Year Fixed Effects & YES \\
\hline Payment Instrument Fixed Effects & YES \\
\hline Control Variables & YES \\
\hline F-test (Wald test) & $151.7 * * *$ \\
\hline Adjusted R-squared & 0.340 \\
\hline
\end{tabular}

Note: Coefficients from OLS regressions, where the dependent variable is individual $i$ 's change in raw perception of security of payment method $j$ from wave $t-1$ to wave $t$. Variables are normalized so that coefficients represent the standard deviation changes for a one-standard-deviation-change in the independent variables. Standard errors clustered at individual level are in parentheses. Significance at the 5\%, and $1 \%$ level is indicated by $* *$ and $* * *$. 
Table 7: An individual's changes in perceptions of security based on divergence from the regional and national averages, age group comparison (marginal effects)

\begin{tabular}{|c|c|c|c|c|c|c|}
\hline & \multicolumn{6}{|c|}{ Dependent Variable: $\Delta S E C_{i j s t}$} \\
\hline & \multicolumn{3}{|c|}{ Age 18-34 } & \multicolumn{3}{|c|}{ Age $>=55$} \\
\hline & State & $\begin{array}{l}\text { Census } \\
\text { Region }\end{array}$ & National & State & $\begin{array}{l}\text { Census } \\
\text { Region } \\
\end{array}$ & National \\
\hline$S E C_{i j s, t-1}-\overline{S E C}_{-i, j s, t-1}$ & $\begin{array}{l}-0.624 * * * \\
(0.02)\end{array}$ & $\begin{array}{l}-0.626 * * * \\
(0.02)\end{array}$ & $\begin{array}{l}-0.628 * * * \\
(0.02)\end{array}$ & $\begin{array}{l}-0.583 * * * \\
(0.02)\end{array}$ & $\begin{array}{l}-0.586 * * * \\
(0.01)\end{array}$ & $\begin{array}{l}-0.587 * * * \\
(0.01)\end{array}$ \\
\hline Age & $\begin{array}{l}-0.007 \\
(.01)\end{array}$ & $\begin{array}{l}-0.008 \\
(.01)\end{array}$ & $\begin{array}{l}-0.005 \\
(.01)\end{array}$ & $\begin{array}{l}0.028 * * \\
(.00)\end{array}$ & $\begin{array}{l}0.029 * * \\
(.00)\end{array}$ & $\begin{array}{l}0.029 * * \\
(.00)\end{array}$ \\
\hline Education: High school & $\begin{array}{l}-0.010 \\
(0.16)\end{array}$ & $\begin{array}{l}-0.009 \\
(0.15)\end{array}$ & $\begin{array}{l}-0.006 \\
(0.15)\end{array}$ & $\begin{array}{l}-0.024 \\
(0.11)\end{array}$ & $\begin{array}{c}-0.026 \\
(0.11)\end{array}$ & $\begin{array}{l}-0.027 \\
(0.11)\end{array}$ \\
\hline Education: Some college & $\begin{array}{l}-0.009 \\
(0.15)\end{array}$ & $\begin{array}{l}-0.010 \\
(0.14)\end{array}$ & $\begin{array}{l}-0.010 \\
(0.14)\end{array}$ & $\begin{array}{l}0.033 \\
(0.11)\end{array}$ & $\begin{array}{l}0.035 \\
(0.11)\end{array}$ & $\begin{array}{l}0.035 \\
(0.11)\end{array}$ \\
\hline Education: College degree & $\begin{array}{l}-0.010 \\
(0.15)\end{array}$ & $\begin{array}{l}-0.015 \\
(0.15)\end{array}$ & $\begin{array}{l}-0.011 \\
(0.14)\end{array}$ & $\begin{array}{l}0.026 \\
(0.11)\end{array}$ & $\begin{array}{l}0.029 \\
(0.11)\end{array}$ & $\begin{array}{l}0.029 \\
(0.11)\end{array}$ \\
\hline Education: Post-graduate studies & $\begin{array}{l}0.001 \\
(0.16)\end{array}$ & $\begin{array}{l}0.002 \\
(0.15)\end{array}$ & $\begin{array}{l}0.004 \\
(0.15)\end{array}$ & $\begin{array}{l}0.022 \\
(0.11)\end{array}$ & $\begin{array}{l}0.025 \\
(0.11)\end{array}$ & $\begin{array}{l}0.024 \\
(0.11)\end{array}$ \\
\hline Married & $\begin{array}{l}-0.004 \\
(0.06)\end{array}$ & $\begin{array}{l}-0.005 \\
(0.06)\end{array}$ & $\begin{array}{l}-0.006 \\
(0.06)\end{array}$ & $\begin{array}{l}-0.009 \\
(0.03)\end{array}$ & $\begin{array}{l}-0.009 \\
(0.03)\end{array}$ & $\begin{array}{l}-0.008 \\
(0.03)\end{array}$ \\
\hline Income: $\$ 25,000$ - $\$ 49,999$ & $\begin{array}{l}0.007 \\
(0.08)\end{array}$ & $\begin{array}{l}0.012 \\
(0.08)\end{array}$ & $\begin{array}{l}0.013 \\
(0.08)\end{array}$ & $\begin{array}{l}-0.007 \\
(0.05)\end{array}$ & $\begin{array}{l}-0.009 \\
(0.05)\end{array}$ & $\begin{array}{l}-0.009 \\
(0.05)\end{array}$ \\
\hline Income: $\$ 50,000-\$ 74,999$ & $\begin{array}{l}-0.002 \\
(0.09)\end{array}$ & $\begin{array}{l}0.001 \\
(0.09)\end{array}$ & $\begin{array}{l}0.002 \\
(0.09)\end{array}$ & $\begin{array}{l}-0.007 \\
(0.05)\end{array}$ & $\begin{array}{l}-0.009 \\
(0.05)\end{array}$ & $\begin{array}{l}-0.009 \\
(0.05)\end{array}$ \\
\hline Income: $\$ 75,000-\$ 99,000$ & $\begin{array}{l}0.041 \\
(0.10)\end{array}$ & $\begin{array}{l}0.040 \\
(0.11)\end{array}$ & $\begin{array}{l}0.040 \\
(0.11)\end{array}$ & $\begin{array}{l}0.010 \\
(0.06)\end{array}$ & $\begin{array}{l}0.007 \\
(0.06)\end{array}$ & $\begin{array}{l}0.007 \\
(0.06)\end{array}$ \\
\hline Income: over $\$ 100,000$ & $\begin{array}{l}0.031 \\
(0.11)\end{array}$ & $\begin{array}{l}0.032 \\
(0.11)\end{array}$ & $\begin{array}{l}0.033 \\
(0.11)\end{array}$ & $\begin{array}{l}0.010 \\
(0.05)\end{array}$ & $\begin{array}{l}0.008 \\
(0.05)\end{array}$ & $\begin{array}{l}0.008 \\
(0.05)\end{array}$ \\
\hline Male & $\begin{array}{l}0.039 * * \\
(0.05)\end{array}$ & $\begin{array}{l}0.037 * * \\
(0.05)\end{array}$ & $\begin{array}{l}0.038 * * \\
(0.05)\end{array}$ & $\begin{array}{l}0.034 * * * \\
(0.03)\end{array}$ & $\begin{array}{l}0.036^{* * * *} \\
(0.03)\end{array}$ & $\begin{array}{l}0.037 * * * \\
(0.03)\end{array}$ \\
\hline White & $\begin{array}{l}-0.029 \\
(0.06) \\
\end{array}$ & $\begin{array}{l}-0.028 \\
(0.07) \\
\end{array}$ & $\begin{array}{l}-0.027 \\
(0.07)\end{array}$ & $\begin{array}{l}-0.008 \\
(0.05) \\
\end{array}$ & $\begin{array}{l}-0.007 \\
(0.06) \\
\end{array}$ & $\begin{array}{l}-0.008 \\
(0.06) \\
\end{array}$ \\
\hline $\mathbf{N}$ & 6229 & 6229 & 6229 & 21605 & 21605 & 21605 \\
\hline Year Fixed Effects & YES & YES & YES & YES & YES & YES \\
\hline Payment Instrument Fixed Effects & YES & YES & YES & YES & YES & YES \\
\hline F-test (Wald test) & $47.93 * * *$ & $47.45^{* * *}$ & $46.89 * * *$ & $164.14 * * *$ & 164.14 & $164.26 * * *$ \\
\hline Adjusted R-squared & .377 & .380 & .382 & .326 & .329 & .330 \\
\hline
\end{tabular}

Note: Marginal effects from OLS regressions, where the dependent variable is individual i's change in raw perception of security of payment $j$ from wave $t-1$ to wave $t . S E C_{i j s, t-1}-\overline{S E C}_{-i, j s, t-1}$ is the difference between individual $i$ 's raw perception of security and the average raw perception of security in the state of residence, census region of residence, or national average, as noted. Variables are normalized so that coefficients represent the standard deviation changes for a one-standard-deviation-change in the independent variables. Explanatory variables are individual characteristics that are thought to be exogenous to perceptions of security such as age, education, income, and marital status. Standard errors clustered at individual and payment instrument level are in parentheses. Significance at the $5 \%$, and $1 \%$ level is indicated by $* *$ and $* * *$. 
Table 8: Impact of a close friend's negative safety shock on one's own overall safety assessment

\begin{tabular}{|c|c|c|c|c|c|c|}
\hline & Checks & Debit Cards & Credit Cards & Store Value Cards & BANP & OBBP \\
\hline ID Thef $t_{i, t}$ (marginal effects) & $-0.210 * *$ & $-0.161 * *$ & -0.121 & 0.030 & $-0.169 * *$ & -0.039 \\
\hline Pr=1 Very Risky & $0.008 * * *$ & $0.010^{* *}$ & 0.007 & -0.004 & $0.023 * *$ & 0.002 \\
\hline Pr=2 Risky & $0.036 * * *$ & $0.026 * *$ & 0.017 & -0.002 & $0.016 * *$ & 0.005 \\
\hline Pr=3 Neither risky nor secure & 0.001 & -0.002 & 0.003 & 0.001 & $-0.008 * *$ & 0.002 \\
\hline $\operatorname{Pr}=4$ Secure & $-0.038 * * *$ & $-0.029 * *$ & -0.019 & 0.003 & $-0.024 * *$ & -0.006 \\
\hline \multirow[t]{2}{*}{ Pr=5 Very secure } & $-0.009 * * *$ & $-0.008 * *$ & -0.008 & 0.002 & $-0.007 * *$ & -0.003 \\
\hline & $(0.07)$ & $(0.07)$ & $(0.08)$ & $(0.07)$ & $(0.08)$ & $(0.08)$ \\
\hline \multirow[t]{2}{*}{ Age } & $0.021 * * *$ & $-0.010 * * *$ & -0.002 & -0.001 & $0.010 * * *$ & $0.007 * *$ \\
\hline & $(0.00)$ & $(0.00)$ & $(0.00)$ & $(0.00)$ & $(0.00)$ & $(0.00)$ \\
\hline \multirow{2}{*}{ Education: High school } & 0.172 & 0.447 & 0.116 & -0.032 & 0.193 & 0.239 \\
\hline & $(0.26)$ & $(0.24)$ & $(0.25)$ & $(0.18)$ & $(0.22)$ & $(0.29)$ \\
\hline \multirow[t]{2}{*}{ Education: Some college } & -0.251 & 0.149 & 0.013 & -0.101 & 0.003 & 0.401 \\
\hline & $(0.25)$ & $(0.22)$ & $(0.24)$ & $(0.17)$ & $(0.21)$ & $(0.28)$ \\
\hline \multirow{2}{*}{ Education: College degree } & -0.122 & 0.054 & 0.367 & -0.139 & -0.098 & $0.594 * *$ \\
\hline & $(0.26)$ & $(0.23)$ & $(0.24)$ & $(0.17)$ & $(0.22)$ & $(0.28)$ \\
\hline \multirow[t]{2}{*}{ Education: Post-graduate studies } & -0.050 & 0.180 & 0.439 & -0.269 & 0.068 & 0.481 \\
\hline & $(0.26)$ & $(0.24)$ & $(0.25)$ & $(0.18)$ & $(0.23)$ & $(0.29)$ \\
\hline \multirow[t]{2}{*}{ Married } & -0.027 & $-0.169 * *$ & -0.112 & -0.116 & -0.102 & -0.020 \\
\hline & $(0.08)$ & $(0.08)$ & $(0.08)$ & $(0.07)$ & $(0.09)$ & $(0.09)$ \\
\hline \multirow[t]{2}{*}{ Income: $\$ 25,000$ - $\$ 49,999$} & -0.005 & -0.085 & 0.072 & 0.026 & -0.172 & 0.090 \\
\hline & $(0.11)$ & $(0.11)$ & $(0.11)$ & $(0.10)$ & $(0.12)$ & $(0.13)$ \\
\hline \multirow[t]{2}{*}{ Income: $\$ 50,000$ - $\$ 74,999$} & -0.061 & -0.152 & 0.097 & -0.045 & -0.025 & $0.338 * *$ \\
\hline & $(0.12)$ & $(0.12)$ & $(0.12)$ & $(0.11)$ & $(0.13)$ & $(0.14)$ \\
\hline \multirow[t]{2}{*}{ Income: $\$ 75,000$ - $\$ 99,000$} & 0.017 & -0.045 & $0.334 * *$ & -0.091 & 0.018 & $0.431 * *$ \\
\hline & $(0.14)$ & $(0.14)$ & $(0.14)$ & $(0.13)$ & $(0.15)$ & $(0.16)$ \\
\hline \multirow[t]{2}{*}{ Income: over $\$ 100,000$} & -0.135 & 0.008 & $0.481 * * *$ & -0.120 & 0.065 & $0.484 * *$ \\
\hline & $(0.13)$ & $(0.13)$ & $(0.13)$ & $(0.12)$ & $(0.14)$ & $(0.15)$ \\
\hline \multirow[t]{2}{*}{ Male } & $0.188 * *$ & $0.279 * * *$ & $0.343 * * *$ & $0.191 * *$ & $0.207^{*} *$ & $0.193^{* *}$ \\
\hline & $(0.07)$ & $(0.07)$ & $(0.07)$ & $(0.07)$ & $(0.08)$ & $(0.08)$ \\
\hline \multirow[t]{2}{*}{ White } & 0.164 & -0.085 & $0.274 * *$ & 0.149 & $-0.214 * *$ & 0.068 \\
\hline & $(0.11)$ & $(0.11)$ & $(0.11)$ & $(0.09)$ & $(0.11)$ & $(0.12)$ \\
\hline $\mathbf{N}$ & 5237 & 5233 & 5234 & 5233 & 4459 & 4460 \\
\hline Year Fixed Effects & YES & YES & YES & YES & YES & YES \\
\hline Individual Fixed Effects & YES & YES & YES & YES & YES & YES \\
\hline F-test (Wald test) & $158.953 * * *$ & $123.127 * * *$ & $185.031 * * *$ & $70.337 * * *$ & $185.330^{* * *}$ & $72.884 * * *$ \\
\hline Log-Likelihood & -7377.961 & -7574.810 & -7646.104 & -8143.956 & -6634.996 & -6641.884 \\
\hline
\end{tabular}

Notes: This table presents coefficient estimates from random-effects ordered logit regressions. Dependent variables reflect the overall perceived safety level of payment instruments, taking on a value ranging from 1 (very risky) to 5 (very secure). The dummy identity theft takes on a value of 1 if the individual is well acquainted with someone who has been victim of identity theft, and 0 otherwise. Significance at the $5 \%$, and $1 \%$ level is indicated by $* *$ and $* * *$. 
Table 9: An individual's changes in perceptions of security by distance from peers' perceptions (robustness tests)

\begin{tabular}{|c|c|c|c|}
\hline & \multicolumn{3}{|c|}{ Dependent Variable: $\Delta S E C_{i j s t}$} \\
\hline & Model 1 & Model 2 & Model 3 \\
\hline$S E C_{i, j, s, t-1}-\overline{S E C}_{-i, j, s, t-1}$ & $\begin{array}{c}-0.593 * * * * \\
(0.01)\end{array}$ & $\begin{array}{c}-0.597 * * * \\
(0.01)\end{array}$ & $\begin{array}{c}-0.593 * * * \\
(0.01)\end{array}$ \\
\hline$\overline{S E C}_{j, s, t-1}-\overline{S E C}_{j, t-1}$ & $\begin{array}{c}-0.058^{* * * *} \\
(0.07) \\
\end{array}$ & $\begin{array}{c}-0.058 * * * \\
(0.07) \\
\end{array}$ & $\begin{array}{c}-0.059 * * * \\
(0.07) \\
\end{array}$ \\
\hline $\mathbf{N}$ & 44457 & 44379 & 44457 \\
\hline Year Fixed Effects & YES & NO & NO \\
\hline Payment Instrument Fixed Effects & YES & YES & YES \\
\hline Additional Controls & NO & YES & NO \\
\hline F-test (Wald test) & $606.2 * * *$ & $393.7 * * *$ & $1031.3^{* * *}$ \\
\hline Adjusted R-squared & 0.344 & 0.345 & 0.344 \\
\hline
\end{tabular}

Note: Marginal effects from OLS regressions, where the dependent variable is individual $i$ 's change in raw perception of security from wave $t-1$ to wave $t$. Variables are normalized so that coefficients represent the standard deviation changes for a one-standard-deviation-change in the independent variables. Standard errors clustered at individual level are in parentheses. Significance at the 5\%, and $1 \%$ level is indicated by $* *$ and $* * *$. 
Table 10: The impact of social spillovers on payment behavior

\begin{tabular}{|c|c|c|c|c|c|c|c|c|c|c|c|c|}
\hline & \multicolumn{2}{|c|}{ Check } & \multicolumn{2}{|c|}{ Debit Card } & \multicolumn{2}{|c|}{ Credit Card } & \multicolumn{2}{|c|}{ SVC } & \multicolumn{2}{|c|}{ BANP } & \multicolumn{2}{|c|}{ OBBP } \\
\hline & Adoption & Use & Adoption & Use & Adoption & Use & Adoption & Use & Adoption & Use & Adoption & Use \\
\hline Security (own) $t-1$ & $\begin{array}{l}0.00 * \\
(1.78)\end{array}$ & $\begin{array}{l}0.00 \\
(0.54)\end{array}$ & $\begin{array}{c}0.03 * * * \\
(7.59)\end{array}$ & $\begin{array}{c}0.02 * * * \\
(4.20)\end{array}$ & $\begin{array}{c}0.00 \\
(0.74)\end{array}$ & $\begin{array}{c}0.01 * * \\
(2.85)\end{array}$ & $\begin{array}{l}-0.00 \\
(-0.59)\end{array}$ & $\begin{array}{c}0.00 \\
(0.70)\end{array}$ & $\begin{array}{c}0.01 * * \\
(3.24)\end{array}$ & $\begin{array}{c}0.01 \\
(1.67)\end{array}$ & $\begin{array}{c}0.05 * * * \\
(10.45)\end{array}$ & $\begin{array}{c}0.01 * * * \\
(3.79)\end{array}$ \\
\hline Security (average state) $t-1$ & $\begin{array}{c}0.036^{* *} \\
(2.58)\end{array}$ & $\begin{array}{c}0.01 \\
(0.89)\end{array}$ & $\begin{array}{c}0.03 \\
(1.29)\end{array}$ & $\begin{array}{c}0.05^{* * *} \\
(2.75)\end{array}$ & $\begin{array}{c}0.02 \\
(1.28)\end{array}$ & $\begin{array}{c}-0.01 \\
(-0.76)\end{array}$ & $\begin{array}{c}-0.07 * * \\
(-2.23)\end{array}$ & $\begin{array}{l}-0.03 \\
(-1.17)\end{array}$ & $\begin{array}{l}-0.03 \\
(-1.23)\end{array}$ & $\begin{array}{l}-0.02 \\
(-1.19)\end{array}$ & $\begin{array}{c}0.04 \\
(1.83)\end{array}$ & $\begin{array}{c}0.02 \\
(1.51)\end{array}$ \\
\hline Acceptance $_{t-1}$ & $\begin{array}{c}0.00 \\
(0.48)\end{array}$ & $\begin{array}{c}0.01 * * * \\
(3.44)\end{array}$ & $\begin{array}{c}0.03 * * * \\
(4.73)\end{array}$ & $\begin{array}{c}0.03 * * * \\
(5.77)\end{array}$ & $\begin{array}{c}0.01 \\
(1.74)\end{array}$ & $\begin{array}{c}-0.01 * * \\
(-2.57)\end{array}$ & $\begin{array}{c}0.00 \\
(0.52)\end{array}$ & $\begin{array}{c}0.00 \\
(0.65)\end{array}$ & $\begin{array}{l}-0.00 \\
(-0.70)\end{array}$ & $\begin{array}{c}0.00 \\
(0.98)\end{array}$ & $\begin{array}{l}0.02 * * \\
(3.04)\end{array}$ & $\begin{array}{c}0.01 * * * \\
(4.21)\end{array}$ \\
\hline $\operatorname{Cost}_{t-1}$ & $\begin{array}{c}0.02 * * * \\
(6.05)\end{array}$ & $\begin{array}{c}-0.00 * * \\
(-2.27)\end{array}$ & $\begin{array}{c}0.05^{* * * *} \\
(11.23)\end{array}$ & $\begin{array}{c}0.02 * * * \\
(3.62)\end{array}$ & $\begin{array}{c}0.02 * * * \\
(8.07)\end{array}$ & $\begin{array}{c}0.05 * * * \\
(21.99)\end{array}$ & $\begin{array}{l}-0.00 \\
(-0.54)\end{array}$ & $\begin{array}{c}0.00 \\
(0.10)\end{array}$ & $\begin{array}{c}0.04 * * * \\
(7.18)\end{array}$ & $\begin{array}{l}0.02 * * \\
(2.64)\end{array}$ & $\begin{array}{c}0.04 * * * \\
(7.78)\end{array}$ & $\begin{array}{c}0.01 * * * \\
(3.46)\end{array}$ \\
\hline Convenience $_{t-1}$ & $\begin{array}{c}0.01 * * * \\
(3.92)\end{array}$ & $\begin{array}{c}0.03 * * * \\
(16.30)\end{array}$ & $\begin{array}{c}0.07 * * * \\
(15.65)\end{array}$ & $\begin{array}{c}0.09 * * * \\
(10.26)\end{array}$ & $\begin{array}{c}0.03 * * * \\
(8.21)\end{array}$ & $\begin{array}{c}0.04 * * * * \\
(9.82)\end{array}$ & $\begin{array}{l}0.01 * * \\
(2.44)\end{array}$ & $\begin{array}{c}0.01 \\
(1.30)\end{array}$ & $\begin{array}{c}0.03^{* * * *} \\
(5.89)\end{array}$ & $\begin{array}{l}0.01 * * \\
(2.90)\end{array}$ & $\begin{array}{c}0.09 * * * \\
(17.88)\end{array}$ & $\begin{array}{c}0.04 * * * \\
(5.48)\end{array}$ \\
\hline Mills Ratio & & $\begin{array}{c}-0.07 * * * \\
(-3.52) \\
\end{array}$ & & $\begin{array}{c}0.13 * * \\
(2.36) \\
\end{array}$ & & $\begin{array}{c}0.12 * * * \\
(3.97) \\
\end{array}$ & & $\begin{array}{c}0.13 \\
(0.84) \\
\end{array}$ & & $\begin{array}{l}0.14 * * \\
(3.41) \\
\end{array}$ & & $\begin{array}{c}0.22 * * * \\
(2.38) \\
\end{array}$ \\
\hline $\begin{array}{l}\text { Observations } \\
\text { Wald Test }\end{array}$ & \multicolumn{2}{|c|}{$\begin{array}{c}7862 \\
1768 * * *\end{array}$} & \multicolumn{2}{|c|}{7852} & \multicolumn{2}{|c|}{7884} & \multicolumn{2}{|c|}{6080} & \multicolumn{2}{|c|}{7769} & \multicolumn{2}{|c|}{7833} \\
\hline
\end{tabular}

Notes: This table presents coefficient estimates of a Heckman two-step model. Table entries for adoption are the marginal effects estimates from the probit regression in the first stage of the Heckman two-step model. The dependent variable in adoption models is set equal to 1 if the respondent has adopted the payment type, and 0 otherwise. Table entries for use are coefficient estimates from the second stage of the Heckman selection model. The dependent variable in the use models is the share of total payments made with that payment type. The Heckman two-step procedure excludes respondents who have missing values in the second stage only if the dependent variable of the first stage is equal to 1, that is, if they had adopted the payment method. Z-statistics are reported in parenthesis. Significance at the $10 \%, 5 \%$, and $1 \%$ level is indicated by $*, * *$ and $* * *$. 


\section{Appendix \\ Positive and negative perceptions: transformation of base specification}

Equation (2) in the paper can be shown as:

$y=\alpha+\beta_{1} X+\beta_{2} N E G+\beta_{3}(X * N E G)$,

where $X$ is an independent variable, NEG is a dummy variable, and $X^{*}$ NEG is an interaction term.

NEG $=1$ if a consumer perceives a payment instrument as riskier than her peers do.

$\mathrm{NEG}=0$ if a consumer perceives a payment instrument as more secure than her peers do.

The interaction term in (A1) makes the interpretation of the effect of NEG on y difficult.

In order to interpret the effect more easily, we can split the dummy NEG into two dummy variables, the original NEG and a new one called POS (which is the variable NEG=0). For example:

\begin{tabular}{|c|c|c|}
\hline Original Variable & \multicolumn{2}{|c|}{ Transformed Variable } \\
\hline NEG & NEG & POS \\
\hline 1 & 1 & 1 \\
\hline 0 & 0 & 0 \\
\hline 1 & 1 & 1 \\
\hline 0 & 0 & 1 \\
\hline 0 & 0 & 0 \\
\hline 1 & 1 & 0 \\
\hline 1 & 1 & 0 \\
\hline
\end{tabular}

We use the new dummies NEG and POS to split the variable $X$ into two groups based on whether a consumer perceives an instrument as riskier or more secure than her peers do. It will also allow us to see the impact of these two groups on the dependent variable separately.

Hence, we can rewrite equation (A1) as follows:

$$
\begin{aligned}
& y=\alpha+\underbrace{\beta_{1} X}_{\beta_{1}(X * N E G)+\beta_{1}(X * P O S)}+\beta_{2} N E G+\beta_{3}(X * N E G) \\
& y=\alpha+\beta_{1}(X * N E G)+\beta_{1}(X * P O S)+\beta_{2} N E G+\beta_{3}(X * N E G) .
\end{aligned}
$$

Rearranging terms of equation (A2):

$$
y=\alpha+\beta_{2} N E G+\beta_{1}(X * P O S)+\left(\beta_{1}+\beta_{3}\right) *(X * N E G)
$$


Equation (A3) above is similar to equation (3) in the paper. Note that there is no multicollinearity in the model, because we are not introducing directly the three dummies NEG, NEG, POS, but using interactions terms with the independent variable $X$. 


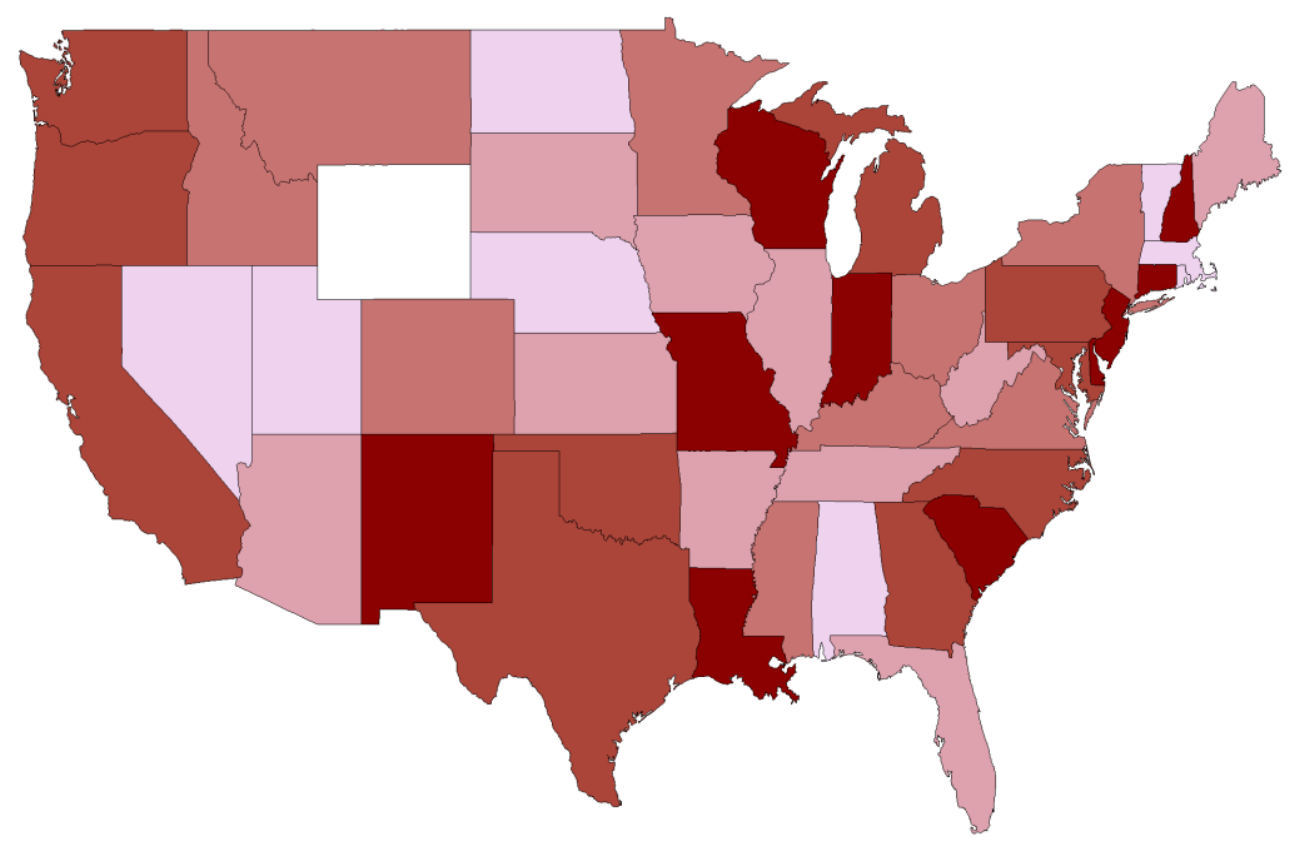

Security Ratings, Relative to Other States (1=Most Risky, 5=Most Safe)

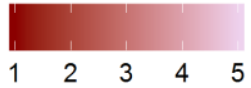

\section{Notes:}

1. White indicates insufficient data for the corresponding state

2. Relative security rating is calculated as a percentile rank among all 50 states and the District of Columbia. State averages for each payment instrument in each year are ordered and assigned a number based on the following percentiles:

- $1 \%-20 \%=1$ (Most Risky)

- $21 \%-40 \%=2$

- $41 \%=60 \%=3$

- $61 \%-80 \%=4$

- $81 \%-100 \%=5$ (Most Secure) 
Table A1: Security ratings, by state, 2008-2014 average and standard deviation

\begin{tabular}{|c|c|c|}
\hline & \\
\hline & $\begin{array}{c}\text { Average, } \\
\text { 2008-2014 } \\
\text { (weighted) }\end{array}$ & $\begin{array}{l}\text { Standard } \\
\text { Deviation }\end{array}$ \\
\hline Alaska (AK) & 4.60 & 0.55 \\
\hline Alabama (AL) & 3.57 & 1.27 \\
\hline Arizona (AZ) & 2.71 & 1.60 \\
\hline Arkansas (AR) & 2.71 & 1.11 \\
\hline California (CA) & 2.14 & 0.90 \\
\hline Colorado (CO) & 2.57 & 1.27 \\
\hline Connecticut (CT) & 2.29 & 1.25 \\
\hline Delaware (DE) & 3.14 & 1.68 \\
\hline Florida (FL) & 3.00 & 0.82 \\
\hline Georgia (GA) & 2.86 & 0.69 \\
\hline Hawaii (HI) & 5.00 & 0.00 \\
\hline Idaho (ID) & 3.14 & 1.57 \\
\hline Illinois (IL) & 3.29 & 0.95 \\
\hline Indiana (IN) & 1.71 & 0.49 \\
\hline Iowa (IA) & 4.43 & 0.53 \\
\hline Kansas (KS) & 2.57 & 1.51 \\
\hline Kentucky (KY) & 3.57 & 1.51 \\
\hline Louisiana (LA) & 2.00 & 1.15 \\
\hline Maine (ME) & 4.14 & 0.90 \\
\hline Maryland (MD) & 3.00 & 1.15 \\
\hline Massachusetts (MA) & 2.57 & 1.51 \\
\hline Michigan (MI) & 2.57 & 0.79 \\
\hline Minnesota (MN) & 2.86 & 1.21 \\
\hline Mississippi (MS) & 3.29 & 1.60 \\
\hline Missouri (MO) & 2.14 & 1.07 \\
\hline Montana (MT) & 3.71 & 1.60 \\
\hline Nebraska (NE) & 3.43 & 1.40 \\
\hline Nevada (NV) & 3.71 & 1.38 \\
\hline New Hampshire (NH) & 2.43 & 1.81 \\
\hline New Jersey (NJ) & 2.57 & 1.40 \\
\hline New Mexico (NM) & 1.57 & 0.79 \\
\hline New York (NY) & 2.71 & 1.25 \\
\hline North Carolina (NC) & 2.71 & 0.95 \\
\hline North Dakota (ND) & 2.71 & 1.89 \\
\hline Ohio (OH) & 2.57 & 1.13 \\
\hline Oklahoma (OK) & 3.43 & 0.98 \\
\hline Oregon $(\mathrm{OR})$ & 2.57 & 1.27 \\
\hline Pennsylvania (PA) & 2.57 & 0.98 \\
\hline Rhode Island (RI) & 2.86 & 1.86 \\
\hline South Carolina (SC) & 3.29 & 1.11 \\
\hline South Dakota (SD) & 4.57 & 0.53 \\
\hline Tennessee (TN) & 2.29 & 1.25 \\
\hline Texas (TX) & 2.86 & 1.07 \\
\hline Utah (UT) & 3.00 & 1.73 \\
\hline Vermont (VT) & 3.43 & 1.99 \\
\hline Virginia (VA) & 3.43 & 0.53 \\
\hline Washington (WA) & 2.86 & 1.35 \\
\hline West Virginia (WV) & 3.57 & 1.51 \\
\hline Wisconsin (WI) & 1.86 & 0.90 \\
\hline Wyoming (WY) & 2.50 & 1.73 \\
\hline Washington D.C. (WDC) & 3.50 & 1.97 \\
\hline
\end{tabular}


Table A2: Descriptive statistics (divergence from peers' perceptions)

\begin{tabular}{|c|c|c|c|c|c|c|}
\hline Payment Instrument & Variable & Observations & Mean & Std. Dev. & Min & $\operatorname{Max}$ \\
\hline \multirow{3}{*}{ Check } & Own minus state average security & 9,068 & .0211 & 1.108 & -3.00 & 2.82 \\
\hline & State average minus national average & 9,122 & .0030 & 0.193 & -0.97 & 1.18 \\
\hline & National average in year $t$ minus national average over all years & 13,165 & -.0001 & 0.074 & -0.18 & 0.11 \\
\hline \multirow{3}{*}{ Debit Card } & Own minus state average security & 9,065 & -.0030 & 1.188 & -3.50 & 3.00 \\
\hline & State average minus national average & 9,122 & -.0004 & 0.186 & -1.15 & 1.17 \\
\hline & National average in year $t$ minus national average over all years & 13,165 & -.0001 & 0.110 & -0.17 & 0.15 \\
\hline \multirow{3}{*}{ Credit Card } & Own minus state average security & 9,067 & .0138 & 1.243 & -3.33 & 3.00 \\
\hline & State average minus national average & 9,122 & .0018 & 0.205 & -0.98 & 1.74 \\
\hline & National average in year $t$ minus national average over all years & 13,165 & -.0002 & 0.138 & -0.24 & 0.17 \\
\hline \multirow{3}{*}{ SVC } & Own minus state average security & 9,056 & .0027 & 1.311 & -3.50 & 3.33 \\
\hline & State average minus national average & 9,122 & .0006 & 0.215 & -1.83 & 1.27 \\
\hline & National average in year $t$ minus national average over all years & 13,165 & -.0002 & 0.095 & -0.26 & 0.13 \\
\hline \multirow{3}{*}{ OBBP } & Own minus state average security & 8,213 & .0092 & 1.258 & -3.04 & 2.60 \\
\hline & State average minus national average & 8,260 & -.0023 & 0.214 & -1.03 & 1.27 \\
\hline & National average in year $t$ minus national average over all years & 12,169 & -.0001 & 0.065 & -0.13 & 0.07 \\
\hline \multirow{3}{*}{ BANP } & Own minus state average security & 8,212 & .0024 & 1.267 & -2.47 & 3.67 \\
\hline & State average minus national average & 8,260 & .0000 & 0.196 & -1.04 & 1.06 \\
\hline & National average in year $t$ minus national average over all years & 12,169 & -.0002 & 0.152 & -0.28 & 0.17 \\
\hline
\end{tabular}


Table A3: Correlation between average raw perception of security and crime indicators (per thousands of individuals) at the state level

\begin{tabular}{|c|c|c|c|c|c|c|c|c|c|c|c|c|c|c|}
\hline $\begin{array}{l}\text { Raw security assessment } \\
\text { (checks) }\end{array}$ & 1 & & & & & & & & & & & & & \\
\hline $\begin{array}{l}\text { Raw security assessment } \\
\text { (Debit Cards) }\end{array}$ & 0.2202 & 1 & & & & & & & & & & & & \\
\hline $\begin{array}{l}\text { Raw security assessment } \\
\text { (Credit Cards) }\end{array}$ & 0.3466 & 0.4501 & 1 & & & & & & & & & & & \\
\hline $\begin{array}{l}\text { Raw security assessment } \\
\text { (Stored value Cards) }\end{array}$ & 0.2079 & 0.255 & -0.0605 & 1 & & & & & & & & & & \\
\hline $\begin{array}{l}\text { Raw security assessment } \\
\text { (OBBP) }\end{array}$ & 0.1778 & 0.2137 & 0.4254 & -0.2089 & 1 & & & & & & & & & \\
\hline $\begin{array}{l}\text { Raw security assessment } \\
\text { (BANP) }\end{array}$ & 0.4546 & 0.3951 & 0.3943 & 0.0436 & 0.4056 & 1 & & & & & & & & \\
\hline Violent crime & -0.0654 & -0.0867 & -0.1261 & -0.0095 & -0.147 & -0.0735 & 1 & & & & & & & \\
\hline $\begin{array}{l}\text { Murder and no negligent } \\
\text { Manslaughter }\end{array}$ & -0.066 & -0.0767 & -0.1262 & -0.0103 & -0.1663 & -0.0701 & 0.9771 & 1 & & & & & & \\
\hline Forcible rape & -0.0673 & -0.0707 & -0.1227 & 0.0097 & -0.1367 & -0.0855 & 0.9345 & 0.9212 & 1 & & & & & \\
\hline Robbery & -0.0524 & -0.0968 & -0.1256 & -0.0214 & -0.1359 & -0.0741 & 0.9789 & 0.9698 & 0.9002 & 1 & & & & \\
\hline Aggravated assault & -0.0709 & -0.0804 & -0.1235 & -0.0043 & -0.15 & -0.0703 & 0.9934 & 0.9615 & 0.9252 & 0.9499 & 1 & & & \\
\hline Property crime total & -0.0816 & -0.0658 & -0.1184 & -0.0024 & -0.1338 & -0.0802 & 0.9668 & 0.9557 & 0.9592 & 0.9408 & 0.9584 & 1 & & \\
\hline Burglary & -0.0802 & -0.0467 & -0.1073 & 0.01 & -0.1347 & -0.0841 & 0.9406 & 0.9347 & 0.9467 & 0.904 & 0.9375 & 0.9879 & 1 & \\
\hline Larceny-theft & -0.0735 & -0.0682 & -0.1185 & -0.0019 & -0.1352 & -0.0735 & 0.9602 & 0.9463 & 0.9552 & 0.9321 & 0.9529 & 0.996 & 0.9779 & 1 \\
\hline Motor vehicle theft & -0.1159 & -0.0811 & -0.1226 & -0.0292 & -0.1036 & -0.0977 & 0.9122 & 0.9074 & 0.8647 & 0.9223 & 0.8881 & 0.8981 & 0.8725 & 0.8641 \\
\hline
\end{tabular}


Table A4: New adopters model probit regressions (marginal effects)

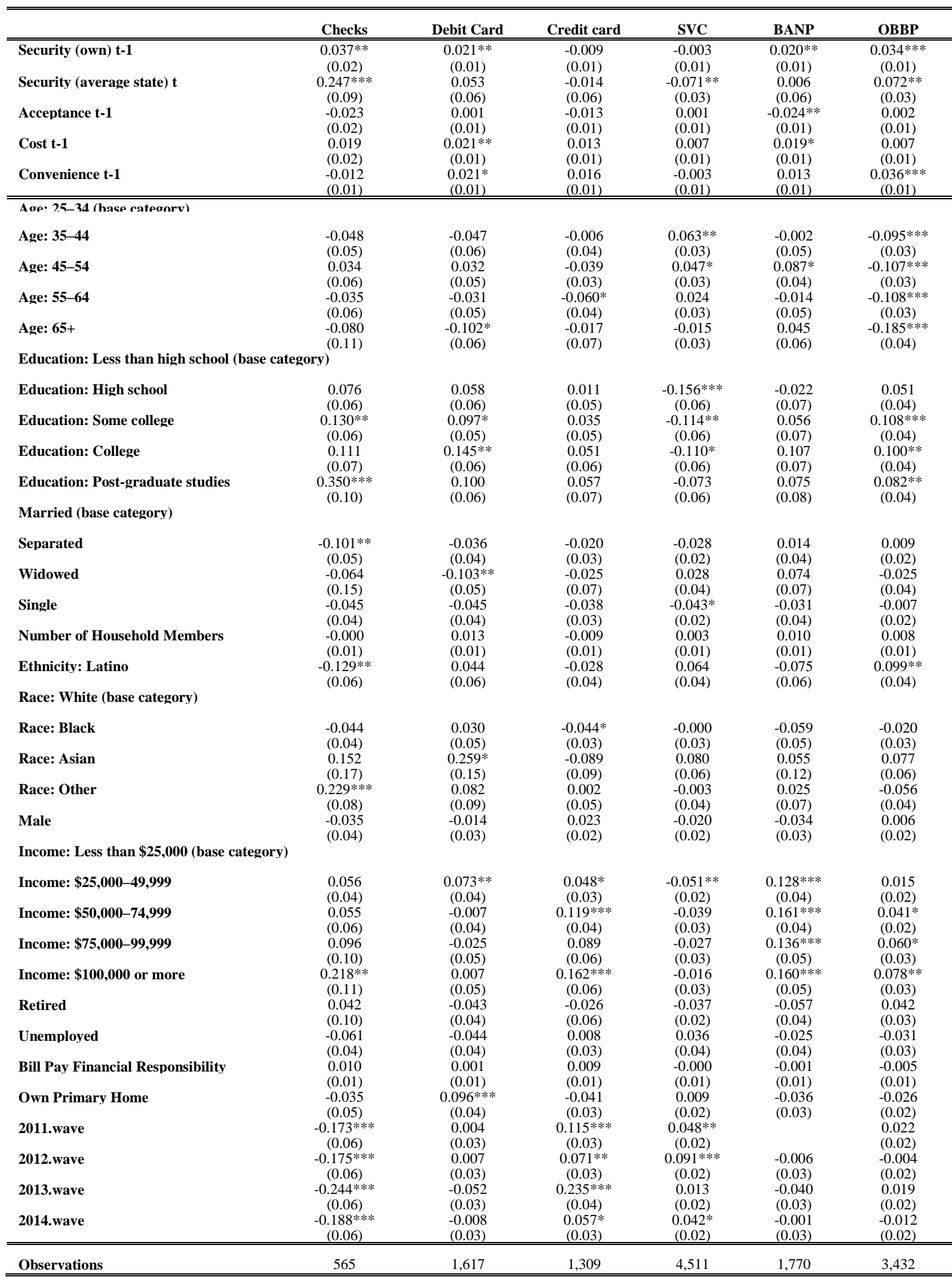

Notes: Table entries are the marginal effects estimates from the probit regressions. The dependent variable is set equal to 1 if the respondent is a new adopter in $t$ of a particular payment type (conditional on having being a nonadopter in $t-1$ ).

Otherwise, it equals 0 . All variables are lagged one period. Standard errors reported in parenthesis. Significance at the $10 \%$, $5 \%$, and $1 \%$ level is indicated by $*, * *$ and $* * *$. 